\title{
How to Restore
}

\section{Sustainability of the Euro?}

Kari E.O. Alho* 
The paper is associated with the report Alho, Kotilainen and Nikula (2010). I thank Ville Kaitila, Markku Kotilainen and Niku Määttänen from ETLA as well as the participants of the XXXIII Annual Meeting of the Finnish Economic Association in Oulu for comments to an earlier version of the paper. The usual disclaimer applies.

ISSN 0781-6847 
Contents

$\begin{array}{ll}\text { Abstract } & 2\end{array}$

$1 \quad$ Introduction $\quad 3$

2 The model $\quad 4$

3 Sustainability of the euro: the basic result $\quad 6$

$4 \quad$ Numerical analysis of sustainability within the euro area after an $\begin{array}{lr}\text { idiosyncratic shock in inflation and competitiveness } & 8\end{array}$

$5 \quad$ Sustainability with respect to public deficit and debt $\quad 11$

5.1 Modifications to the model 12

5.2 Simulations on the sustainability of the euro in a debt crisis 14

5.3 Sustainability through structural reforms? 20

$\begin{array}{llr}6 & \text { Concluding remarks } & 21\end{array}$

$\begin{array}{ll}\text { References } & 23\end{array}$

Appendix 1

Derivation of the IS curve in Eq. (1) 24

Appendix 2

Latent roots of the $\mathrm{H}$ matrix on page 7

Appendix 3

The characteristic roots of the extended system for fiscal policy analysis in Section 5.2. 


\begin{abstract}
We reassess the result of unsustainability of the euro with respect to inflation differentials claimed by Wickens (2007) by specifying an open-economy version of a two-region New Keynesian model for EMU and demonstrate that the result by Wickens does not hold in general. We are able to derive a result that the model is determinate for a wide range of policy rules so that the sustainability of the euro area and the member countries is reached over time with respect to supply and demand shocks and emerged imbalances in price levels and competitiveness. We then enlarge the numerical analysis to consider EMU and sustainability in the case, prevailing currently, where a high debt country should both restore its competitiveness and its fiscal balance, and the policies required from the single monetary policy and the national fiscal policies. Strong fiscal consolidation and far-reaching successful structural reforms are needed to reach sustainability in the sense that emerged imbalances in competitiveness and price levels and the threat of ever mounting debt levels could be eliminated over the medium run. We also illustrate how the current deflationary adjustment involves a major polarisation in economic developments within the euro area.
\end{abstract}

Key words: EMU, euro, sustainability, fiscal policy, competitiveness

JEL: E43, E52, E62

\title{
Tiivistelmä
}

Tässä tutkimuksessa tutkitaan Wickensin (2007) esittämää tulosta euroalueen kestämättömyydestä inflaatioerojen suhteen spesifioimalla EMUlle avoimen talouden versio kahden alueen uuskeynesiläisestä mallista. Osoitetaan, että Wickensin tulos ei päde yleisesti. Johdamme tuloksen, että avoimen talouden EMU-mallilla on ratkaisu suurelle joukolle politiikkasääntöjä niin, että euroalue ja sen jäsenmaat konvergoituvat kohti tasapainoa tarjonta- ja kysyntäshokkien jälkeen, kun hintatasot ja kilpailukyvyt ovat aluksi erkaantuneet. Sen jälkeen laajennamme numeerisen analyysin koskemaan nykyisenkaltaista tilannetta, jossa suuresti velkaantunut EMU-maa pyrkii sopeutumaan niin, että se tasapainottaa velkakehitystään ja kilpailukykyään, ja tarkastelemme yhteistä rahapolitiikan ja kansallisten finanssipolitiikkojen yhdistelmää tällaisessa tilanteessa. Tarvitaan voimakasta finanssipolitiikan kiristämistä ja pitkälle meneviä onnistuneita rakenneuudistuksia, jotta kohoava velkasuhde voitaisiin stabiloida keskipitkällä ajalla tällaisessa maassa. Osoitetaan myös, että käynnissä oleva deflatorinen sopeutuminen merkitsee melkoista polarisaatiota euroalueen talouksien kehityksen välillä.

Asiasanat: EMU, euro, kestävyys, finanssipolitiikka, kilpailukyky 


\section{Introduction}

The financial and economic crisis which started in 2007 has delivered a major blow to the global economic system. As typically in a deep recession, the crisis has also caused a tension with respect to the countries obeying a fixed exchange rate system, like the EMU, with diverging economic developments and imbalances within it.

Already before the crisis, Wickens (2007) foresaw and made the observation that the euro has not been sustainable in the sense that the price levels, i.e., the real exchange rates of the participating countries of the euro area have been on an unsustainable divergent path during the first decade of the euro. The high inflation countries at the outset have not experienced lower inflation hence, but quite on the contrary, they have diverged in terms of price levels and competitiveness. He also made the claim that this will be the case in the future as well. Sustainability can only be reached if there are fiscal transfers from the high-inflation country to the lowinflation country, which is unlikely to happen. This unsustainability holds irrespective of the fact that the ECB has a perfect success in its task and capacity to contain inflation in the euro area as an aggregate in the sequel as well.

In this paper, we intend to tackle this same question using a stylized new Keynesian macro model (NKM) for the member countries of the euro area, with a slightly more elaborated specification than that used by Wickens (2007). However, our conclusions are far more comforting than that by him. We argue that his core result does not hold in general with a plausible numerical specification of the model. The model has a determinate solution both for the euro area as a whole and its member countries. We are also able to demonstrate that in the open economy NKM model the euro area as an aggregate and the individual countries have a determinate solution for a wide range of policy rules by the ECB. Also, if there is an inherited divergence in price levels, linked to a loss of competitiveness in a member country, the consequent policy by the ECB is sufficient as to the elimination of this imbalance. In the long run, the initial deviation from parity will vanish, although this can take quite a long time.

Wickens (2007) only considered stability with respect to price levels, while we subsequently enlarge the analysis to consider stability in terms of both price levels and fiscal policy and public debt. The model is reformulated by giving up the assumption of homogeneous financial markets in the euro area and replace it with segmented markets. We study the mutual interrelationship between the ECB and national fiscal policies. However, our approach markedly differs from the recent literature on monetary unions where optimal monetary and fiscal policies are studied, see e.g. Galí and Monacelli (2008), Ferrero (2008) and Orjasniemi (2010), where optimal fiscal policies could be linked to respond to idiosyncratic shocks. Here we rather try to capture a situation, like the current one, where a policy error has been made and imbalances within the euro area have emerged, and policies are basically pursued to stabilise future public debt and competitiveness developments with simple budgetary rules. Numerically, we illustrate a case like that currently in Greece where a rapid pace is required in the elimination of the public deficit, assisted by an EU rescue package. If there is no or only a weak fiscal consolidation, this may entail an unsustainable situation for the euro area in the sense that the imbalances would not be eliminated, or that the mounting public indebtedness would not be prevented within a reasonable horizon. However, the future likely rise in the interest rate set by the ECB casts a doubt on managing the interest burden of accumulating public debt and the success of fiscal consolidation. We also illustrate that the adjustment, although successful, 
to the current divergence in competitiveness and public debt will lead to a major polarisation within EMU in the sense that the problem countries lose and the rest can gain in terms of output during the medium-run adjustment period. And as a last item, we infer that far-reaching successful structural reforms are needed to quickly balance the public debt ratio in the problem EMU country.

We can discern two meanings of the term sustainability. First, we have the case where the NKM model has or does not have a determinate, bounded unique solution. Secondly, if the solution exists, whether it makes sense in the spirit of the sustainability of the public debt so that the emerged imbalances in the euro area in terms of competitiveness differentials and debt ratios will be eliminated within a reasonable time span of, say, the next ten years.

The rest of the paper proceeds in such a way that in the next section we build the two-region model for the EMU, and in Section 3 consider optimal discretionary policy and sustainability of the euro. In Section 4 we calibrate the model numerically and carry out the simulations under a standard Taylor rule for the ECB. In Section 5 we widen the analysis to fiscal policy and public debt. Section 6 concludes.

\section{The model}

We specify the following stylized New Keynesian macro model for the euro area, consisting of two countries, following Wickens (2007), but deviating from it in some key respects. The IS curve is in period the following, for both member countries, $i, j=1,2, i \neq j$,

$$
q_{i, t}=-\beta\left(r_{t}-E \pi_{i, t+1}-\theta\right)+\gamma E q_{i, t+1}+\lambda\left(p_{j, t}-p_{i, t}\right)+\phi\left(s_{t}+p_{t}^{*}-p_{i, t}\right)+\delta q_{j, t}+z_{i, t}+\varepsilon_{i, t},
$$

where $\mathrm{q}$ is the output gap in $\log , \mathrm{r}$ the common interest rate set by the ECB, $\pi$ is the inflation rate, $\mathrm{E}$ is the expectation operator on information in period $t, \theta$ is the equilibrium real rate of interest given by the time preference, $\mathrm{p}$ is the price level in log, $\mathrm{p}^{*}$ the global price level outside the euro area, $s$ is the log of the effective exchange rate of the euro, units of foreign currency per unit of euro, $z$ and $\varepsilon$ the demand impulses stemming from the domestic fiscal policy and the world markets, respectively. In general, a superscript star denotes a global variable. All parameters in (1) are positive. The first two terms on the right-hand side refer to contributions by consumption behaviour and investment to aggregate demand, and the next three terms refer to net exports. So, we depict the influence of the expected real rate of interest, the expected output gap in the next period, the influence of the competitiveness of the country concerned, both within the euro area and in relation to the rest of the world, and the external demand both within the euro area and the world economy outside it. A similar equation applies to the other EMU partner country $j$. In the Appendix 1 we present a more exact derivation of the IS curve.

The supply curve, the inflation rate, measured through a CPI, is determined by the following relationship, depicting also a Calvo pricing mechanism for domestically produced goods,

$$
\pi_{i, t}=\xi_{1} E \pi_{i, t+1}+\xi_{2} \pi_{j, t}+\xi_{3}\left(s_{t}-s_{0}+\pi_{t}^{*}\right)+\alpha q_{i, t}+u_{i, t}, \xi_{1}+\xi_{2}+\xi_{3}=1,
$$


where the subscript 0 denotes an initial value of a variable determined outside the model. The justification of this specification for the supply curve is that the domestic price level is made of goods supplied by the domestic producers, and by imports from the euro area partner and from the global markets (the three first terms on the right-hand side of (2)). In addition, we depict the influence of the output gap on inflation in a standard manner. The supply $\left(\mathrm{u}_{\mathrm{it}}\right)$ shocks in (2) are serially uncorrelated, but observed in the beginning of the period, before the policy by the ECB is decided.

We deviate from Wickens (2007) who took the external value of the euro as fixed and derive its determination as an endogenous item through the portfolio balance. The demand (superscript D) for the euro assets denoted by B (government bonds), the stock $B^{S}$ of which is momentarily given, is determined by investors in the euro area and those in the rest of the world, so that in equilibrium we have,

$$
B_{t}^{S}=B_{i, t}^{D}+B_{j, t}^{D}+s_{t} B_{t}^{D^{*}}
$$

Here we assume that the euro area bonds are perfect substitutes for each other so that within the euro area financial markets are homogeneous, but see, however, below in Section 5. Each demand component $\mathrm{k}$ is determined by the given wealth $\mathrm{W}_{\mathrm{k}}$ and positively by the expected yield differential between the euro area and the rest of the world, $\mathrm{k}=1-3$,

$$
B_{k, t}^{D}=a_{k} \bar{W}_{k, t}^{D} g\left(r_{t}-\left(r_{t}^{*}+E s_{t+1}-s_{t}\right)\right), g^{\prime}>0, g(0)=1,0<a_{k}<1 .
$$

A similar equation holds for the demand for the external assets, which can be skipped through the portfolio balance identity. For simplicity, we assume that the investors in the market have a fixed de/revaluation expectation of the future exchange rate of the euro so that $\mathrm{Es}_{\mathrm{t}+1}-\mathrm{s}_{\mathrm{t}}$ is given by the initial gap in the inflation rates, i.e., it is equal to $\Omega-\pi_{0}^{*}$, where $\Omega$ is the inflation target by the ECB. From (3) and (4) we can derive the reaction that a rise in the euro area interest rate leads to an inflow of capital from abroad and to a revaluation of the external value of the euro, and thereby to disinflation within the euro area through this link as well, see (2),

$$
s_{t}=s_{0}-\psi\left(r_{t}-r_{0}\right), \psi>0 .
$$

In the standard manner, we assume that the two EMU countries in the model are initially symmetric and of equal size. This means that all the reaction parameters in the above country model are identical for countries $i$ and $j$.

The ECB takes the aggregate euro area indicators, denoted by a bar, as a basis for its policy. These are in the symmetric case,

$$
\bar{q}=\frac{q_{i}+q_{j}}{2}, \bar{\pi}=\frac{\pi_{i}+\pi_{j}}{2} .
$$

The model for the aggregate euro area is then given by the following behavioural equations,

$$
\begin{aligned}
& (1-\delta) \bar{q}_{t}=-\beta\left(r_{t}-E \bar{\pi}_{t+1}-\theta\right)+\gamma E \bar{q}_{t+1}+\phi\left(s_{t}+p_{t}^{*}-\bar{p}_{t}\right)+\bar{z}_{t}+\bar{\varepsilon}_{t} \\
& \left(1-\xi_{2}\right) \bar{\pi}_{t}=\xi_{1} E \bar{\pi}_{t+1}+\xi_{3}\left(s_{t}-s_{0}+\pi_{t}^{*}\right)+\alpha \bar{q}_{t}+\bar{u}_{t} .
\end{aligned}
$$


From the supply curve (8) we find that when the purchasing power parity (PPP) holds, i.e., the expected inflation rate is equal to the global inflation measured in euro then the expected euro area output gap is zero given that there are no supply shocks in the euro area. Similarly, we find that if this holds in each member country as well, then the expected value of the output gap is zero, $E q_{i, t}=E q_{j, t}=0$, and output is at the natural level in each country. From (8) we infer, using the above result concerning expected change in the exchange rate that, in equilibrium,

$$
E \bar{\pi}_{t}=\Omega+\frac{\alpha}{1-\xi_{1}-\xi_{2}} E \bar{q}_{t}+\frac{1}{1-\xi_{1}-\xi_{2}} \bar{u}_{t}
$$

\section{Sustainability of the euro: the basic result}

We could start, as Wickens (2007) did, from a discretionary formulation of the monetary policy by the ECB. However, this effort is not in effect needed, and in the rest of the paper we assume that the ECB follows a Taylor type of rule in its policy making, see below Equation (12). However, in order to be able to argue about the conclusion of Wickens, we first state the basic outcome of the policy-making. It is well known that the central bank fully offsets the effects of aggregate demand shocks. This means that in the absence of the supply shocks the expected (for the next period) and the current period output gap is zero. As mentioned above, this holds in the steady state long-run equilibrium.

Let us then insert, similarly as Wickens (2007) did, the ECB policy into the IS curves (1) for both countries $i$ and $j$. Let us take expectations of the IS curves, and simplify the system by approximating that the expected output gaps in period $\mathrm{t}+1$ are zero for both countries. Then by subtracting the IS curves for i and $\mathrm{j}$ from each other and using the identity, $E \pi_{i, t+1}=E p_{i, t+1}-p_{i t}$ the following dynamic equation can be readily derived for differentials of logs of price levels,

$$
p_{i t}-p_{j t}=\frac{\beta}{\beta+2 \lambda+\phi}\left(E p_{i, t+1}-E p_{j, t+1}\right)+\frac{1}{\beta+2 \lambda+\phi}\left(\left(z_{i t}-z_{j t}\right)+\left(\varepsilon_{i t}-\varepsilon_{j t}\right)\right) .
$$

This is a determinate difference equation with a unique bounded solution based on the future path of the fiscal and demand shock differentials, in contrast to that stated by Wickens (2007), as the coefficient of the forward-looking variable is smaller than unity, see King and Watson (1998) and Sargent $(1989,216)$, Lubik and Schorfheide (2004) and Galí (2010) for a general treatment of the NKM model. This requires that the fiscal impulses and the demand shocks do not diverge from each other more rapidly than with the exponential order of $(\beta+2 \lambda+\phi) / \beta$. Meeting this, if there is an initial idiosyncratic shock to the price levels, they converge over time. This takes place in conjunction with the fact that the euro area as a whole stays well in a stable way within the goals adopted by the ECB, see below.

However, this is not how Wickens (2007) treats this equation (10) and Minford and Srinisavan (2010) consider the NKM model in a similar way to him. Both start from a shock to the initial price level or the price differential in (10) and then trace the future path of the price differential. Both then use Eq. (10) or the like in the NKM model in effect as a backward-looking equation to trace the future path. Wickens (2007) argues that the ECB can do nothing to pre- 
vent this divergence in price level deviations to mount over time. But we argue that this interpretation of the NKM model is not correct.

We now have a large system of four forward-looking difference equations, the analysis of which is quite awkward and, therefore, we have adopted a simpler approach, constructed below.

Let us next turn to a comprehensive analysis of the model for differences between the EMU countries $i$ and $j$, embedded in the above NKM model. From the output equations (1) and the inflation equations (2) we can derive the following expression for the relative output gaps and inflation differential, denoted by the symbol d, e.g., $d q_{t}=\left(q_{i t}-q_{j t}\right) / 2$,

$$
\begin{array}{cc}
(1+\delta) d q_{t}+(2 \lambda+\phi) d \pi_{t}=\gamma E d q_{t+1}+\beta E d \pi_{t+1}+d z_{t}+d \varepsilon_{t} \\
-\alpha d q_{t}+\left(1+\xi_{1}+\xi_{2}\right) d \pi_{t}= & \xi_{1} E d \pi_{t+1}+d u_{t}
\end{array}
$$

Let us denote by $\mathrm{A}_{0}$ the matrix of coefficients of the vector ( $\left.\mathrm{dq} \mathrm{d} \pi\right)^{\prime}$ on the left-hand side and by $A_{1}$ the corresponding matrix on the right-hand side of (11). Then a necessary and sufficient condition for a unique and stable solution for (11) is that both the characteristic roots of the matrix $H=A_{0}^{-1} A_{1}$ lie inside the unit circle, see Galí (2010), as there are two forward-looking variables. An analysis of the roots of this matrix in closed form is very awkward in our case, and therefore a numerical analysis is called for. With the numerical values adopted in this paper for the parameters, see Section 4, the values for the roots of the $\mathrm{H}$ matrix are real and lie in the interval $(0,1)$, leading to stability. In Appendix 2 we report a limited sensitivity analysis of this outcome.

Turn then to the monetary policy rules. Below we shall analyse rules of the Taylor type of the following kind,

$$
r_{t}=r^{*}+\omega_{1} \bar{q}_{t}+\omega_{2}\left(\bar{\pi}_{t}-\Omega\right), \text { where } \omega_{i}>0
$$

Let us next turn to consider the determinateness of the aggregate euro area, the model of which was presented above in Eqs. (7) and (8). In the prototype case of a closed economy the NKM model as such, i.e. without the monetary policy reaction, is not determinate, see Galí (2010). The model can be made as determinate if $\omega_{2}>1$, see e.g. Woodford (2003) and Galí (2010). In contrast to the standard NKM model for a closed economy, an analytic evaluation of the latent roots of this matrix $\mathrm{H}$ is in our case quite difficult and therefore a numerical analysis is called for. However, in our specification of the open economy model for the aggregate of the euro area we come to the conclusion that it is stable as such and under a wide range of policy rules, under the set of parameters adopted below, see the Appendix $2 .{ }^{1}$

We have now come to the conclusion that both the models for the aggregate euro area and the difference between the EMU countries are stable. We can now infer that the individual EMU countries have a determinate solution as a linear combination, being either a sum or a difference of these two models, too, given that the shock processes do not diverge too fast from each other.

This basically depends on the open economy specification of the model, see the Appendix 1 . If we discard these items, we come to the basic case of an indeterminate solution of the model which can be eliminated with having $\omega_{2}>1$. 


\section{$4 \quad$ Numerical analysis of sustainability within the euro area after an idiosyncratic shock in inflation and competitiveness}

We illustrate the above two-region EMU model with simulations using a numerical specification. We choose the following fairly standard or plausible values for the parameters (see the Appendix 1): the inflation target $\Omega$ is $2 \%$ p.a., the same holds for the global inflation $\pi^{\star}, \lambda=$ $0.2, \beta=0.3, \gamma=0.3$ (which is crucial for stability, see more on this Appendix 1), $\alpha=0.3, \delta=$ $0.1, \theta=0.02, \psi=6, \phi=0.2, \xi_{1}=0.5, \xi_{2}=0.3$ and $\xi_{3}=0.2$. The elasticity of substitution between imported goods and home goods is taken to be fairly small, two, which leads to the value of the $\phi$ parameter, see on this also Appendix 1. The openness of the euro area to global trade is taken to be $10 \%$. The reaction parameter $\psi$ in Eq. (5) is based on the evidence between the relation of the euro-dollar rate and the respective interest differential, depicted in Commission $(2008,10)$. The long-run equilibrium of the model is that the interest rate set by the ECB is $4 \%$ p.a., and inflation is on its target of $2 \%$ p.a. in both countries. The standard Taylor rule in (12) has the parameters $\omega_{1}=0.5, \omega_{2}=1.5$ but see on this Section 5.2.

In this section, we carry out the simulations of the model, specified for a quarterly time unit ${ }^{2}$, over the period from 2010, second quarter, to 2040 under the assumption that initial shocks to level (stock) variables take place in $2010 \mathrm{Q} 1$, and the supply shock (flow) during the year 2010Q2 to 2011Q1. This temporal specification does not mean that we aim in this section to trace the current situation in the euro area, but rather want to demonstrate how the equilibrium can be restored after an initial shock. So, i.a., we assume in this section that initially output is on its trend in both countries and that the interest rate is on its equilibrium value, i.e. $4 \%$ p.a. We impose terminal conditions to the model so that the forward-looking variables in the long run reach constant levels.

We now get the following outcome for the gap in $\log$ price levels $\mathrm{p}_{1}-\mathrm{p}_{2}$, i.e., terms of trade within the monetary union, and the output gaps $\mathrm{q}_{1}$ and $\mathrm{q}_{2}$ after a unit ( 1 per cent) asymmetric inflationary supply shock in country $1(i=1, j=2)$ in 2010Q2-2011Q1. We see that after the shocks, the euro area again reaches a parity in price levels, i.e., in competitiveness and the real exchange rates, as envisioned above. Output gaps will also be eliminated over time. Although the equilibrium is eventually restored, convergence to it is quite sluggish with this numerical specification.

The interest rate set by the ECB reacts in the following way, see Fig. 2. The reaction is sharp and initially the policy tightens but then undershoots the steady state situation slowly converging from below upwards to it.

Next, we demonstrate that the policy reaction by the ECB also has the capacity to eliminate a divergence in the price levels (terms of trade), i.e., in competitiveness within the euro area, once this kind of a loss has emerged due to some reason in one EMU country.

So, we assume that similarly as in reality, referred to in the Introduction, country $i=1$ has run into an imbalance in its initial price level and in competitiveness of the magnitude of 10 per cent (in logs) in the initial situation (in 2010 Quarter 1 in the figures) and the ECB follows the 
Figure 1 The price differential and the output gaps after an inflationary supply shock (1 percentage point) in country 1 in 2010Q2-2011Q1

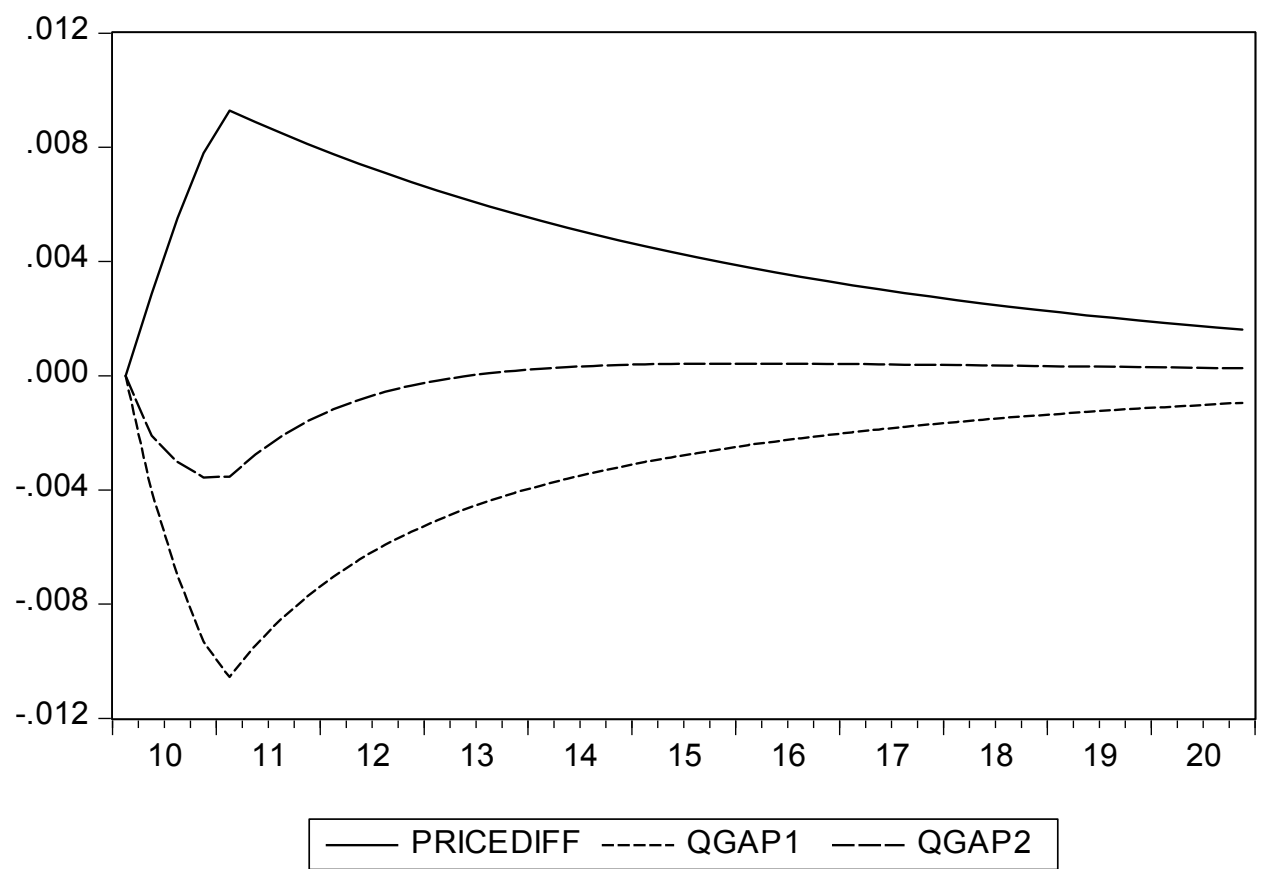

Figure 2 The interest rate policy by the ECB as a reaction to a positive inflation shock in country 1

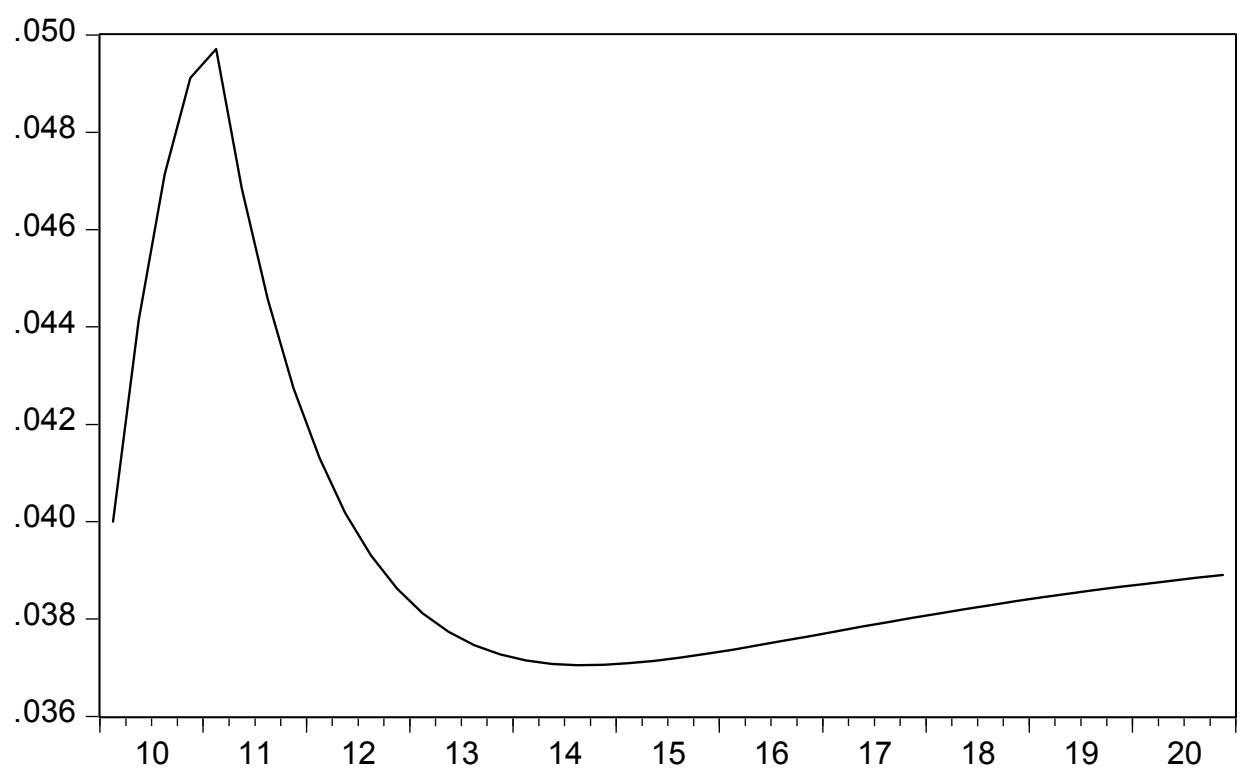

Taylor rule in the above sense. The outcome for the price level differential and the output gaps is now the following, see Fig. 3. 
Figure 3 The price differential and the output gaps after an asymmetric positive price level shock (10 percentage points) in country 1 in $2010 \mathrm{Q} 1$

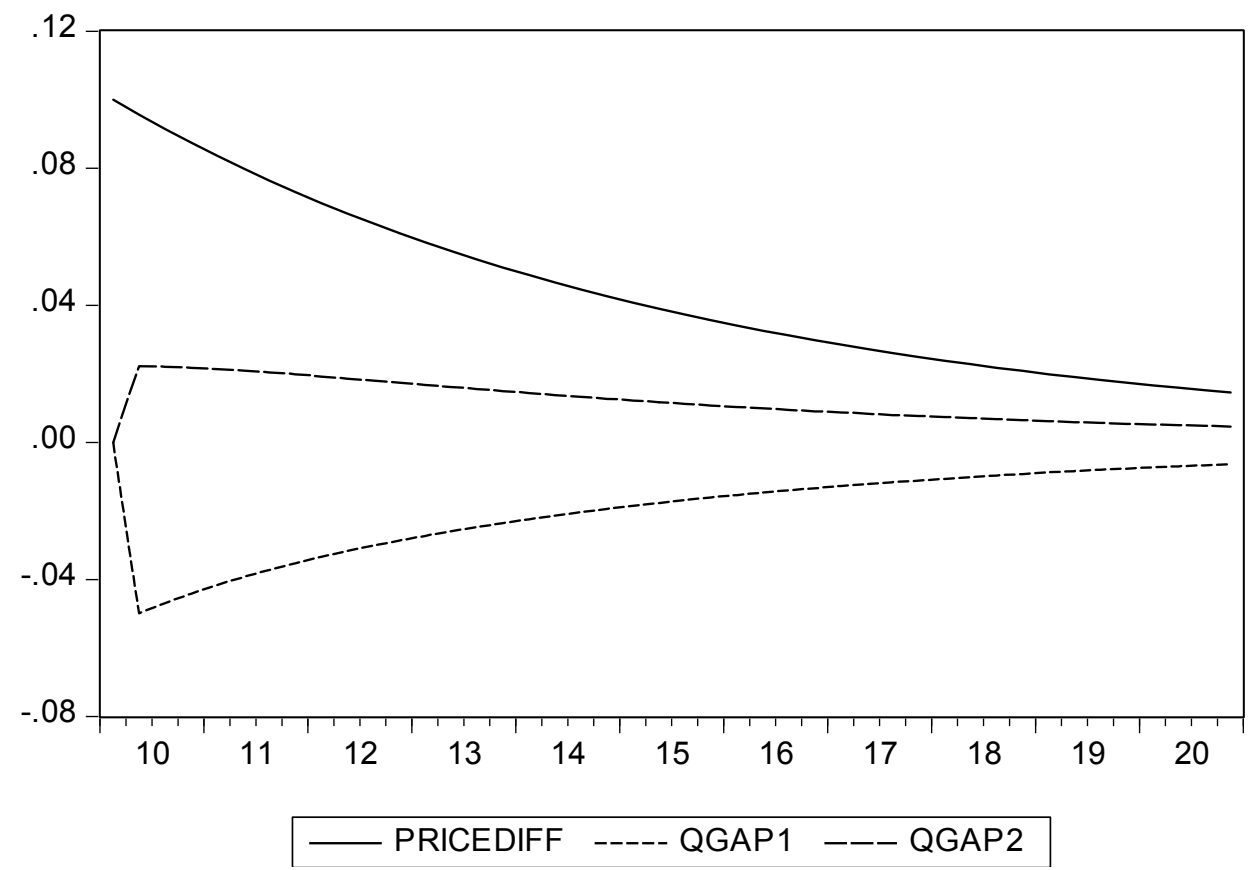

Adjustment within the euro area eliminates the gap in competitiveness and in both the output gaps. We see that adjustment brings in a substantial polarisation within EMU in terms of output reaction. In the EMU country which has lost its competitiveness, the loss in output in the deflationary process is severe, as the output contracts by 4 per cent, while the country in balance with respect to competitiveness gains from the adjustment due to a lower interest rate. The interest rate reaction by the ECB is now the following, see Fig. 4. It is reflationary as the adjustment within the euro area is deflationary, so that the interest rate undershoots the equilibrium interest rate ( $4 \%$ p.a.), initially by more than one percentage point. Now the policy intervention by the ECB is quite long-lasting, although gradually dampening.

In contrast to the standard closed economy NKM model, we can infer that a proper reaction by the ECB is not necessary to reach a determinate solution for the euro area. If the interest rate is passively fixed to the initial equilibrium, the euro area does not diverge in both the above cases, in contrast to the standard literature, see Woodford (2003, Proposition 2.5), and Galí (2010), Lemma 1, see Appendix 2. 
Figure 4 The interest rate policy by the ECB as a reaction to a positive price level, i.e., a negative competitiveness shock in country 1

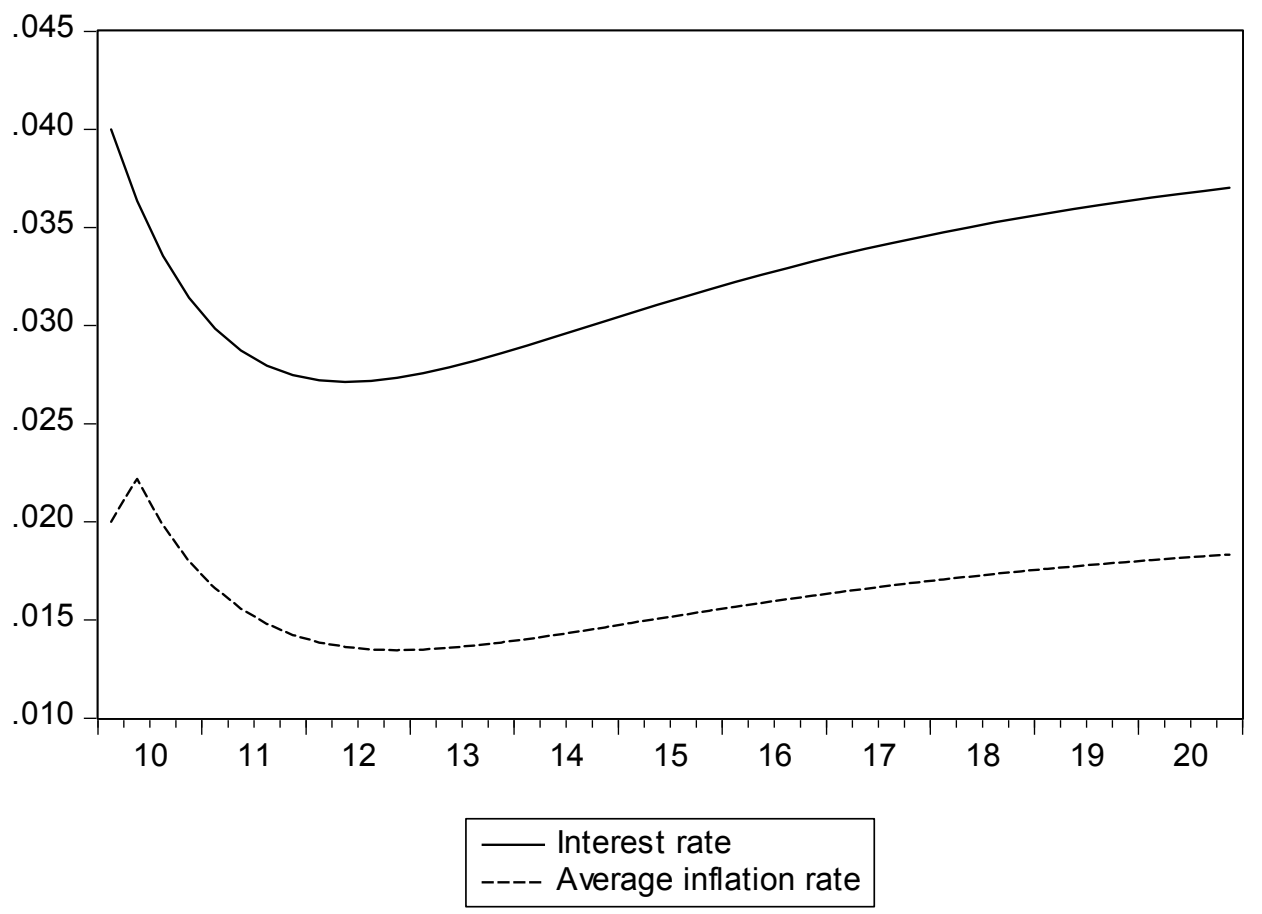

\section{$5 \quad$ Sustainability with respect to public deficit and debt}

Recently, another angle as to the stability of the euro has emerged, namely the robustness of the Monetary Union with respect to a diverging situation in public borrowing and debt. Currently, the EMU has to face the debt crisis of Greece and other so-called PIIGS countries with a large public sector deficit, many of them over $10 \%$ of GDP, and a high debt exceeding $100 \%$ of GDP.

In the initial stage of the EMU more than a decade ago, concern was often raised that the financial markets do not deliver enough sanctions with respect to those countries pursuing lax policy in their public finances. The interest rate differentials have been quite small irrespective of the diverging public indebtedness in the member countries. The present global economic crisis has changed all this. The interest premiums between good and bad borrowers have widened markedly and now the tune has changed from tranquillity to an alarmed consideration of a euro-area country even running into some kind of insolvency, reinforced by excessive market reactions.

The fiscal sustainability has been considered in a NKM model i.a. by Leith and Wren-Lewis (2007) in an optimising framework with several instruments of fiscal policy identified in it, see also Galí and Monacelli (2008), Ferrero (2008) and Orjasniemi (2010). Here our approach deviates from these optimal policy analyses in a fundamental way. We assume that an imbal- 
ance has emerged as currently, and the goal of policy-making is to overcome it, e.g., in public sector indebtedness and competitiveness. We limit ourselves to consider sustainability with respect to an emerged fiscal imbalance in one EMU country so that we only identify the effect of fiscal policy as a demand impulse in the IS curve in Eq. (1) and consider how the public deficit should be reduced and its link to the stability of the euro. ${ }^{3}$

\subsection{Modifications to the model}

The debt dynamics are,

$$
D_{i, t}=\left(1+\bar{r}_{i, t}-\pi_{i, t}\right) D_{i, t-1}+z_{i t} Q_{i, t-1},
$$

where $\mathrm{D}$ is the real public debt (in book value), $\bar{r}$ is the average interest rate on public debt, $z_{\mathrm{i}}$ is now primary deficit in country $\mathrm{i}$ in relation to GDP, and Q is the level of GDP. The actual level of output level evolves as follows,

$$
\log Q_{i, t}=\log Q_{i, t}^{P O T}+q_{i, t} \text {, }
$$

where $\mathrm{Q}^{\mathrm{POT}}$ is the potential output growing at the rate of the trend growth of the labour-augmenting productivity process, see below Section 5.3.

Let us now take as a starting point the current debt crisis in EMU, started in 2010 by the situation in Greece, and the policies adopted to overcome the instability caused by it to the euro. We assume that fiscal policy consists of the components of automatic stabilisers and discretion, where the latter now means a stipulated gradual cut in the initial primary deficit along the announced path in one of the member countries, country $i=1$. Thus we have,

$$
z_{i t}=-h_{1} q_{i, t}+\left[\left(1-h_{2}\right)^{t} z_{i, 0}-h_{3}\right], 0<h_{1}, h_{2}<1, i=1 \text {, }
$$

where the first component captures the automatic stabilizers and the second the discretionary measures in country $i=1$. In the other country $j=2$, only the automatic stabilizers are at play. Above in the previous section we have assumed that the external value of the euro only reacts to the interest rate set by the ECB and the financial markets in the euro area are homogeneous. This is clearly not consistent with the facts of the 2010-2011 euro debt crisis. We assume now that the financial markets in the euro area are segmented so that the bonds of countries $i$ and $j$ are no longer perfect substitutes for each other as they were above in (3). So, their yields deviate according to the extent of the respective government borrowing, see below. The interest rate on the government debt of the problem country rises as the fears of insolvency of the country spread in the market. Second, this also leads to an outflow of capital from the euro area. We should note that the first impact, in itself, leads according to our specification above in (5) to a stronger euro. In order to reach the possibility of a weakening euro, the latter negative impact should be stronger than the first impact. Let us therefore revise the determination of the external value of the euro to take place through the following open interest parity arbitrage condition, incorporating a risk premium,

See, however, below where we allow for an effect on inflation by the fiscal austerity leading to hikes in taxation. 


$$
\frac{\left(1+r^{*}\right) E s_{t+1}}{s_{t}}=1+\frac{r_{1, t}+r_{2, t}}{2}+a_{0}-a_{1}\left(\frac{D_{1, t}}{Q_{1, t}}+\frac{D_{2, t}}{Q_{2, t}}\right), a_{i}>0
$$

where $r^{*}$ is the foreign interest rate and the rates $r_{i}$ and $r_{j}$ now refer to the short-run market rates. This equation can be derived from a portfolio balance model between domestic and foreign assets, where the parameter $\mathrm{a}_{1}$ reflects the attitude toward risk aversion and the risk (variance) of the exchange rate, and GDP marks the size of the portfolio. Now, given the exchange rate expectations, the higher the debt ratio is in the euro area, the more the euro depreciates. In order to reach a determinate solution for Eq. (16), we have to assume that the exchange rate expectations are sluggish. Let us therefore assume simply that $\mathrm{Es}_{\mathrm{t}+1}=\mathrm{s}_{\mathrm{t}-1}+\Omega-\pi^{*}$, similarly as above.

A notable feature of the debt crisis is the markedly widened interest rate differentials in the euro area between the good and bad borrowers. We can introduce the following specification for this differential,

$$
r_{1, t}=r_{t}+\kappa \mu f\left(\frac{D_{1, t}}{Q_{1, t}}\right), f^{\prime}>0, f^{\prime \prime}>0 .
$$

Here the second term captures the expected capital loss related to government bonds of country 1 . The parameter $1-\kappa$ depicts the expected amount of the debt to be paid by the borrower country in the case of its debt default, and $\mu$, multiplied with the convex function $\mathrm{f}$ of the debt ratio, captures the probability of the default by the country $i=1$.

The euro rescue package reached in May 2010 consists of fixed interest rate loans extended to Greece by the other euro area countries at rates lower than the current market interest rates, and similarly for Ireland in November 2010 and Portugal in May 2011. This transfer has the effect that the domestic fiscal impulse in the country $j=2$ is smaller than without this measure by the amount of the interest subsidy extended to the problem country. An equivalent effect, mutatis mutandis, applies to the country $\mathrm{i}=1$.

Based on this reasoning we specify in Eq. (17) that $f\left(d_{t}\right)=0.5 d_{t}+0.5 d_{t}^{2}-d_{12}$, where $\mathrm{d}$ is the debt ratio in country $i=1$ being $100 \%$ initially and $d_{12}$ is the size of the debt of country 1 which country 2 is ready to finance or guarantee. This implies that in the initial stage the probability of default is zero if the euro partner is ready to finance the total debt outstanding. However, over time this probability may become positive, if the country concerned will run into a higher level of debt as will be the case in reality, see below. It is quite unlikely whether the guarantee of the rest of the euro area countries will be extended to cover such a situation as well. It is true that this formulation for the f-function is ad hoc, but in any case the future evolution of the interest spreads in the euro area is quite uncertain at the moment. Let us further tentatively assume that $\kappa=0.5, \mu=0.01$, and initially $d_{12}=0.5$. As took place for Greece in July 2011 when a new package was agreed in the EU summit, we assume that the rescue package is in force in an extended version from 2011Q3 onwards, and does not expire during the simulation period as the maturity of the loans will be extended markedly. So, we specify that $d_{12}$ will now be raised to 0.75 permanently.

One outcome of the crisis in 2010 has been that funds have been channelled to other euro area countries so that the interest rates in Germany and elsewhere with a limited budget deficit, 
like Finland, have been pushed downward. We take this effect simply into account so that for $\mathrm{j}=2$, modifying Laubach (2009),

$$
r_{2, t}=r_{t}+\eta_{2}\left(\frac{D_{2, t}}{Q_{2, t}}-\bar{d}\right)-\eta_{1}\left(\frac{D_{1, t}}{Q_{1, t}}-\bar{d}\right), 0<\eta_{1}<\eta_{2} .
$$

Here $\bar{d}$ is the EMU reference value for the public debt ratio, i.e., 60 per cent. We insert $\mathrm{r}_{\mathrm{i}}$ and $r_{j}$ into the IS curve in Eq. (1) instead of $r$.

The outcomes of the model simulations are problematic also from the point of view that they predict a long-lasting deflation in the euro area. Therefore, we respecify the inflation equation (2) for country $i=1$ by adding to it the impulse on inflation of the taxes raised in order to curb the public deficit. With this aim, we add to it a term depicting the amount by which taxes like VAT are raised to cut the deficit, i.e. the change in the primary deficit multiplied by the share, assumed below to be a half, of it by which amount the tax rate is raised leading to a rise in the price level.

The model comprising also of the fiscal policy block has ten endogenous variables $\left(\mathrm{q}_{1 \mathrm{t}}, \pi_{1 \mathrm{t}}, \mathrm{r}_{1 \mathrm{t}}\right.$, $\left.\mathrm{d}_{1 \mathrm{t}} ; \mathrm{q}_{2 \mathrm{t}}, \pi_{2 \mathrm{t}}, \mathrm{r}_{2 \mathrm{t}}, \mathrm{d}_{2 \mathrm{t}} \mathrm{r}_{\mathrm{t}}, \mathrm{s}_{\mathrm{t}}\right)$, with four forward-looking variables $\left(\mathrm{Eq}_{1, t+1}, \mathrm{E} \pi_{1, t+1}, \mathrm{Eq}_{2, t+1}, \mathrm{E} \pi_{2, t+1}\right)$. We have evaluated the characteristic roots of the $\mathrm{H}$ matrix (see above p. 7) in this case and see that for a wide range of policy reactions the model is stable, see Appendix 3.

\subsection{Simulations on the sustainability of the euro in a debt crisis}

We now turn to the simulations. We will try to trace a situation like the current one in the euro area, at least more than we did in Section 4.

The above specification is not able to describe the current situation in the euro area so that the interest rates would correspond to those realised currently in the European debt crisis. However, to avoid being too far from the reality, we assume below that the short-run interest rate $r_{1}$ of the country $\mathrm{i}=1$ is 2.5 percentage points above the short-term rate set by the ECB throughout, added by the premium described in the previous section in Eq. (17). We further assume that a country has to finance its debts with loans with the maturity of ten years, and that the starting values for the average interest rates on debt in Eq. (13) are 3\% for country 1 and $2 \%$ for country 2 . The future evolution of the interest rate is quite crucial for the sustainability of the fiscal austerity in country 1 , see below.

To further increase realism, we assume that both countries have initially (in 2010) a negative output gap of 4 per cent and face an autocorrelated adverse aggregate demand shock $\varepsilon$ from world markets which vanishes by $10 \%$ per quarter. The size of the initial shock is calibrated in such a way that the aggregate demand initially equalizes output with the stipulated gap. To depict the current situation, we also define that initially country 1 has lost its competitiveness by 10 per cent vis-à-vis the average in the euro area, while country 2 has reached a gain of the same magnitude.

We now specify the rule in (15) to be the following for country $i=1$ in the baseline,

$$
z_{1, t}=-0.5 q_{1, t}+0.09(1-0.6)^{t}-0.01 .
$$


We call a fiscal consolidation according to the rule (19) a strong one, and the case where in Eq. (15) $h_{2}=0.1$ and $h_{2}=0$, a weak one. The magnitude of the automatic stabilizer in (19) is standard, but the fiscal consolidation is arbitrarily fixed, although it is harsh enough to bring in a rapid reduction in the public deficit and, in the end, a ceiling for the public debt - although a very high one - see Figure 6 below. By fixing the $h_{2}$ parameter to this value, we assume that the high debt country cuts its public deficit in relation to GDP initially by more than 3 percentage points per year in its austerity programme, which is consistent with the present desired situation in Greece. In the sequel, we also define a very strong fiscal policy so that the parameter $h_{3}$ is set to the value -0.03. It is true that in (19) we miss the link between the debt ratio and the degree of fiscal consolidation, raised to an important position by Schabert and van Wijnbergen (2011). In country $j=2$ only automatic stabilisers are in operation. We assume that the potential output grows by $2 \%$ p.a. in both countries, but see on this Section 5.3 .

During the crisis the standard monetary policy rules are not at play. This is partly dictated by the zero lower boundary of the nominal interest rate. Therefore, we have replaced in the interest rate rule in Eq. (12) the reaction parameter $\omega_{2}$ with value 0.5 . The interest rate policy by the ECB is as follows, see Fig. 5. The ECB helps in fiscal consolidation in the euro area by a lower interest rate.

In Fig. 6 we see that fiscal austerity can have a perverse effect in the short and medium run as to the debt ratio. Even though the public deficit is cut markedly, the debt ratio in country 1 rises temporarily more rapidly in the case of a strong adjustment than in a weak case as output is squeezed in the short run. In any case the debt ratio rises to a very high level in the problem country $\mathrm{i}=1$. The other EMU partner country is also influenced basically due to the spillover from the lower output in country $i=1$ under a strong fiscal consolidation in this country, see Figure 7.

Figure 5 The interest rate policy by the ECB in the two scenarios

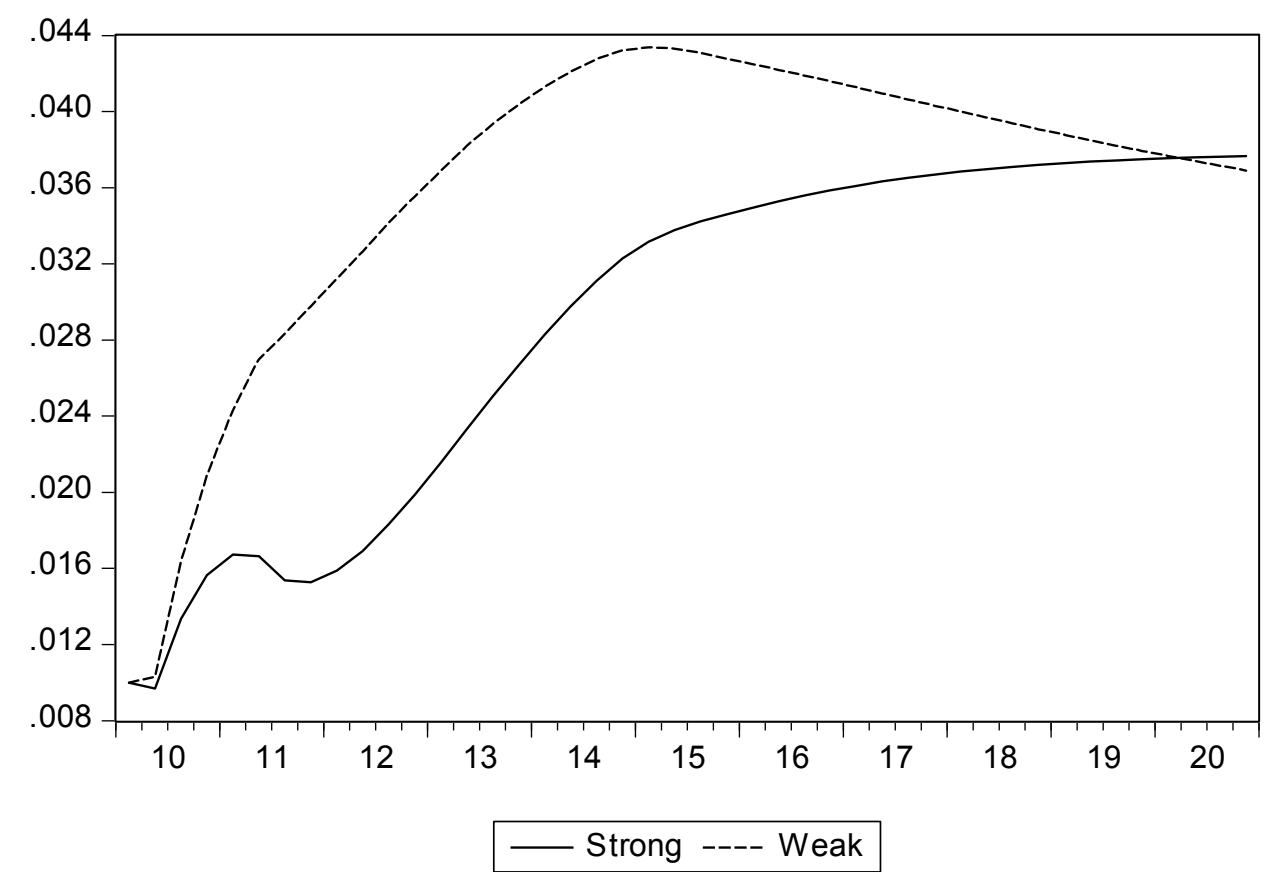


Above in Section 3, we have identified sustainability of the euro in terms of a determinate solution for the euro area and the member countries. From a policy point of view this may be quite far from the reality. Let us therefore examine in the sense of Bergman (2001), whether the evolution of the future public debts meets the no-Ponzi -game assumption. According to this analysis, we estimate a regression of the following kind,

$$
D_{t}=c_{0}+c_{1} D_{t-4}+v_{t}
$$

If the parameter $c_{1}$ is higher than unity plus the discount rate, indicating an explosive debt dynamics, then the no-Ponzi -game condition is not satisfied. In our simulations estimation of this equation for the period 2011-2031 produces the outcome that under a strong fiscal policy the parameter $\mathrm{c}_{1}$ gets the value 1.043 (with $\mathrm{t}$-value 431 ) and under a weak consolidation it gets the value 1.068 (with $t$-value 733 ). This implies that both the weak and strong consolidation policies lead to a situation of being insolvent in terms of debt dynamics. If the problem country 1 could finance throughout its public debt with a fixed interest rate, say $4 \%$ p.a., plus the interest premium in Eq. (17), the public debt in it would be on a sustainable path under a strong fiscal consolidation ( $c_{1}$ would then be clearly less than unity). In this sense we see that the interest rate policy by the ECB, the fiscal policy and the sustainability of the euro are crucially linked together. A likely future rise in the interest rate set the ECB towards the equilibrium value can jeopardise the sustainability of the euro through its spillover effect to the interest burden of the public debt in the problem EMU country.

Figure 6 The public deficit and debt in a high debt, low competitiveness EMU country under an adverse demand and supply shock and fiscal austerity, in relation to GDP (deficit on the left scale, debt on the right) (for explanations, see the text above)

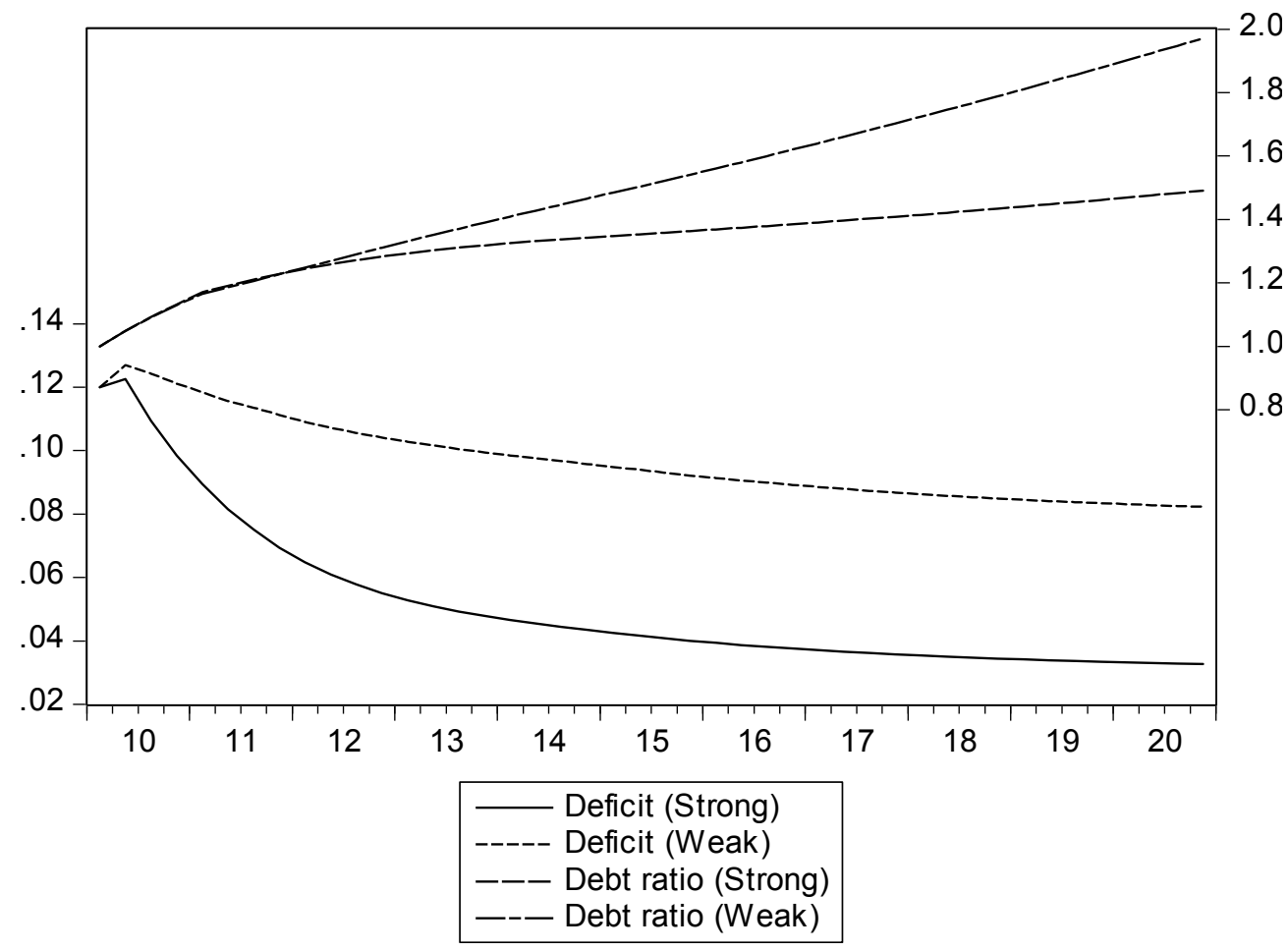




\begin{tabular}{|c|c|c|c|c|c|c|}
\hline Table 1 & $\begin{array}{l}\text { Alternative si } \\
\text { policy in the } \\
\text { fiscal consoli }\end{array}$ & $\begin{array}{l}\text { imulations } \\
\text { problem c } \\
\text { dation }\end{array}$ & $\begin{array}{l}\text { on the link b } \\
\text { untry } 1 \text { und }\end{array}$ & $\begin{array}{l}\text { veen the } \\
\text { various s }\end{array}$ & $\begin{array}{l}\text { rest rate } \\
\text { fications }\end{array}$ & $\begin{array}{l}\text { d the fiscal } \\
\text { a strong }\end{array}$ \\
\hline $\begin{array}{l}\text { Fiscal policy } \\
\text { in country } 1 \\
\text { in Eq. (15) }\end{array}$ & $\begin{array}{l}\text { Interest rater } \\
\text { for new gov- } \\
\text { ernment debt } \\
\text { in country } 1\end{array}$ & $\begin{array}{l}\text { Output gap in } \\
2015, \%\end{array}$ & $\begin{array}{c}\text { Primary balance } \\
\text { (surplus, i.e. }-z_{1} \text { ) } \\
\text { in 2015, \% of } \\
\text { GDP }\end{array}$ & $\begin{array}{l}\text { Debt ratio in } \\
2015, \%\end{array}$ & $\begin{array}{l}\text { Debt ratio in } \\
2030, \%\end{array}$ & $\begin{array}{l}\text { Value of } c_{1} \text { in } \\
\text { Eq. (20) over } \\
\text { the period } \\
2010-2031\end{array}$ \\
\hline $\begin{array}{l}h_{1}=0.6 \\
h_{2}=-0.01\end{array}$ & as in Eq. (17) & -4.5 & -1.9 & 136 & 191 & 1.043 \\
\hline $\begin{array}{l}h_{1}=0.6 \\
h_{2}=-0.01\end{array}$ & $\begin{array}{l}4 \% \text { p.a. added by the } \\
\text { premium in Eq. (17) }\end{array}$ & -4.7 & -1.5 & 132 & 123 & 0.925 \\
\hline $\begin{array}{l}h_{1}=0.6, \\
h_{2}=-0.03\end{array}$ & as in Eq. (17) & -5.4 & -0.3 & 130 & 144 & 1.006 \\
\hline $\begin{array}{l}h_{1}=0.6 \\
h_{2}=-0.03\end{array}$ & $\begin{array}{l}\text { 4\% p.a. added by the } \\
\text { premium in Eq. (17) }\end{array}$ & -5.7 & -0.1 & 128 & 94 & 0.764 \\
\hline
\end{tabular}

The alternative of a strong fiscal austerity does not lead to a rapid fall in the primary deficit. Let us therefore trace effects of an even stronger fiscal consolidation in combination with the interest rate rule for new government debt in country 1 , see Table 1.

The diverse impacts of various policies will be felt over the long run, but over the medium run the outlook is quite independent of the fiscal assumptions, similarly as predicted in the Greece country report by the OECD (2011). Over the long run, the interest burden and the fiscal consolidation will make their effects felt clearly on the sustainability criterion in Eq. (20). The

Figure 7 The debt ratio in the country 2 (for explanations, see the text above)

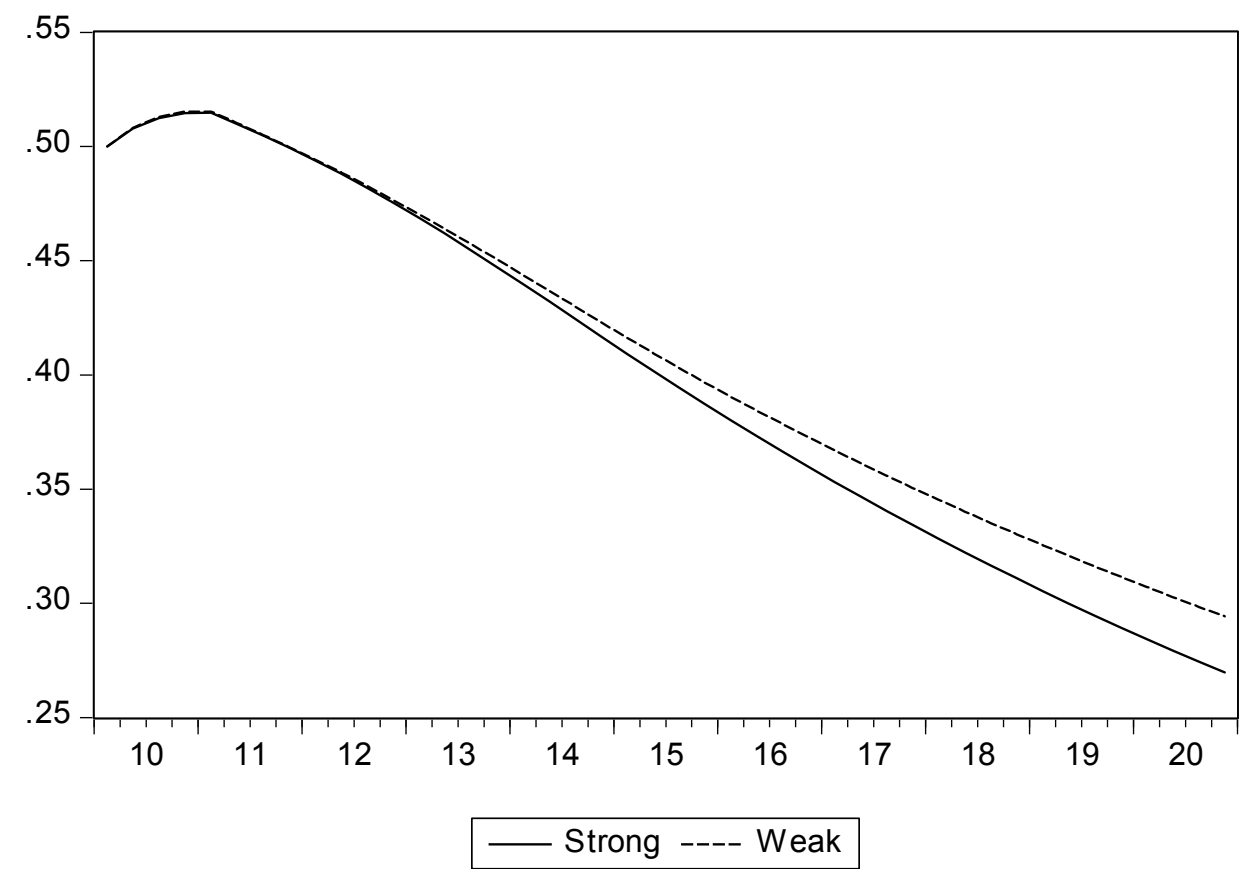


Figure 8 The output gaps in the two EMU countries under a strong fiscal consolidation in country 1 (for explanations, see the text above)

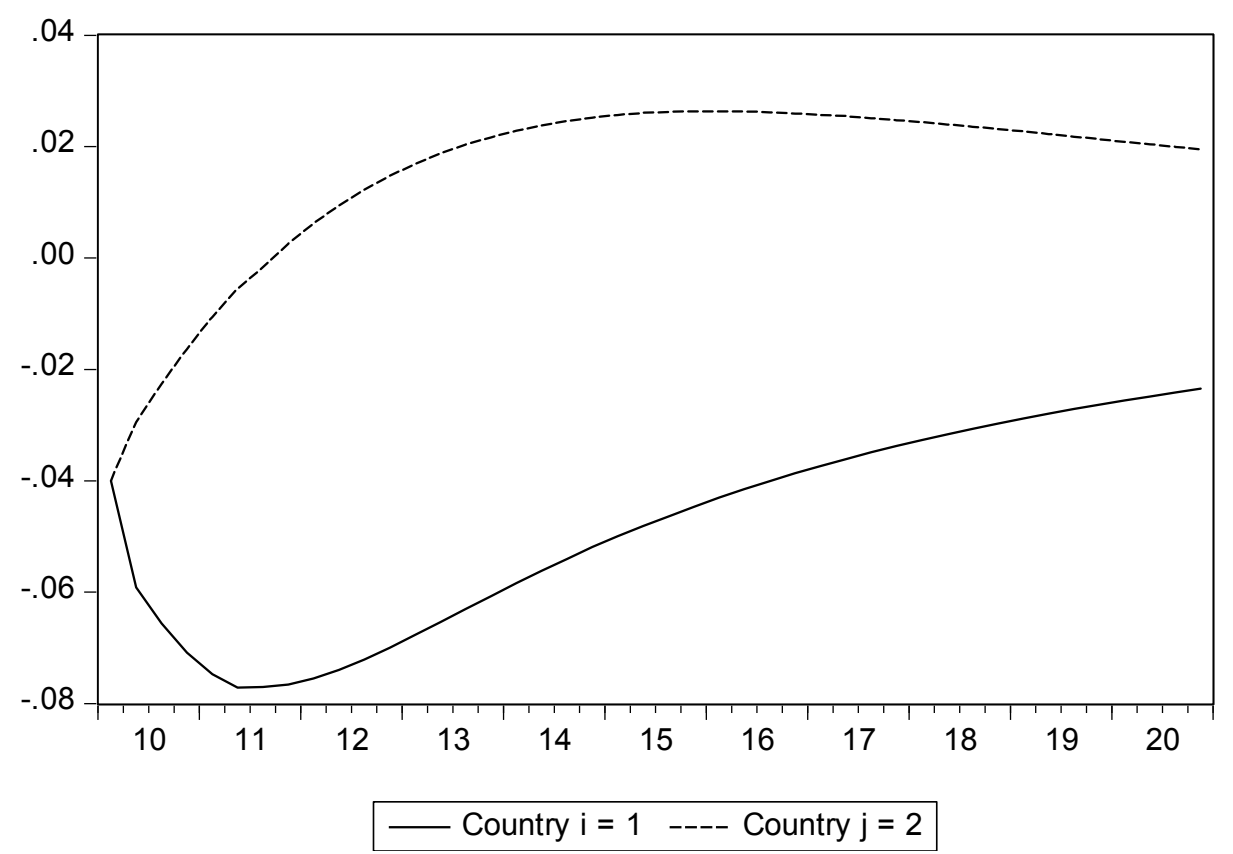

problem in actual policy making lies in the fact that it is very difficult to signal this kind of policy determination in a credible way to the financial markets, which recognise various uncertainties and have normally a much shorter time horizon in their decisions.

Let us then compare the situation under a harsh fiscal adjustment assumed so far compared to a softer one, see Figure 9. We infer that the no-problem country 2 gains in terms of output after a couple of years from a harsh adjustment to the euro debt crisis. On the other hand, the country 1 causing the debt crisis loses sharply and increasingly during the first two years, but then the situation is reversed and it turns towards neutrality. Thus, there is a marked polarization within EMU as a result of the debt crisis. By varying the policy rule in Eq. (15) so that the parameter $h_{2}$ is raised, we can infer that the pain linked to a strong adjustment is higher, but the more rapidly the reduction in the budget deficit takes place in country 1 , the more rapidly it will start to gain from its austere policies. Of course, the measure used here omits many aspects, economic and political, linked to a successful elimination of emerged imbalances within EMU. So, we could argue that a successful consolidation and price adjustment are a condition for a country to be able to permanently reap the microeconomic gains delivered by the participation into the single currency.

We can also depict a difference with respect to the external value of the euro and the average inflation rate. It seems to be the case that over the long run a weak fiscal adjustment to some extent jeopardizes the inflation control in the euro area. Thus the average inflation rate would be on a gradually accelerating trend up to 2015, and it can markedly slow down the price level adjustment after idiosyncratic shocks to competitiveness. We illustrate this in Fig. 10.

The interest rate policy by the ECB is not sufficient alone to hold public sector indebtedness under control. There is thus a limited interaction between monetary and fiscal policy in EMU, 
Figure 9 The difference in the output gaps (output less potential) between the cases of weak and strong fiscal austerity*

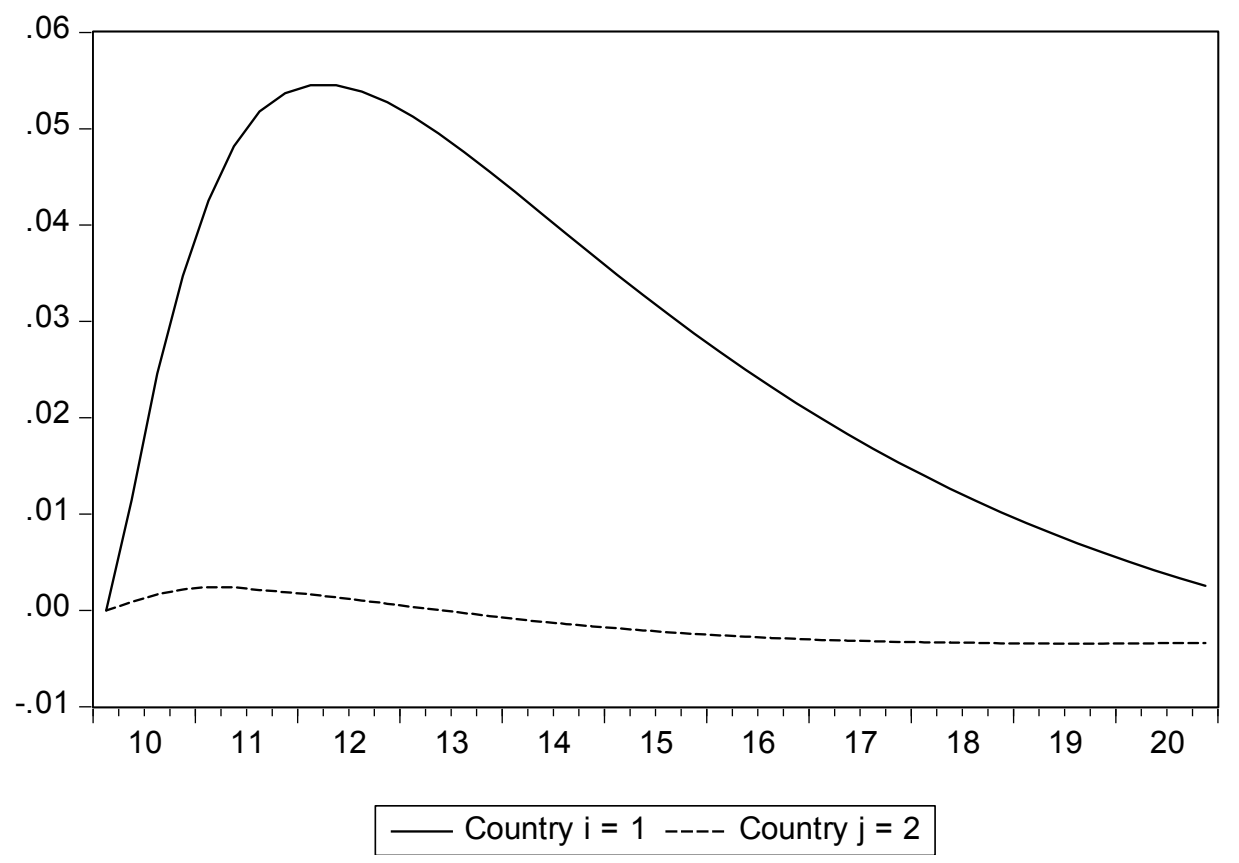

* In this comparison in the weak consolidation case the parameters are as follows in Eq. (15) $h_{1}=-0.5, h_{2}=0.1, h_{3}=0$. The strong consolidation is that stipulated in Eq. (19). The curves denote the difference $q($ weak) $-q($ strong).

as the latter is necessarily needed to manage the current situation of the debt crisis. Of course, the interest rate policy also plays a role, but it is limited in the sense that it cannot alone stabilise output under a demand shock due to the lower boundary for nominal interest rates. In this sense our result reinforces the conventional wisdom, analysed by Kirsanova, Leith and WrenLewis (2009), that monetary policy can be targeted to output stabilisation and fiscal policy to contain public sector finances. But our results sharpen this result in the sense that the fiscal policy adjustment is necessarily needed to assist the ECB in its task of reaching a sustainable non-explosive solution for the euro area.

In the current package of new EU legislation in autumn 2010 aiming to enhance the sustainability of the euro area, a new concept by the EU Commission was launched. In addition to the fundamental concept of Excessive Deficit Procedure of the Stability and Growth Pact a new one, namely Excessive Imbalance Procedure, was introduced. It tackles other types of imbalances in the overall economic developments than just the budget deficit and public debt. The Euro Plus agreement agreed in March 2011 calls for additional adjustment to restore imbalances in competitiveness. The above model shows that fiscal stabilisation can markedly speed up the convergence in price levels (competitiveness), and is in broad terms a sufficient condition for this, see Fig. 10. However, the path back to parity may be quite sluggish. The smaller the parameter $h_{2}$ is in Eq. (20), the slower the price levels converge back to parity. This would suggest that the role of other policies to maintain overall stability could also be of importance. ${ }^{4}$

$4 \quad$ The initial move away from parity is a result of the assumption that a tightening of fiscal policy is made up by in part with raising taxes like VAT, which leads to a hike in the price level. 
Figure 10 The price level differential $\left(p_{1}-p_{2}\right.$, in logs) under a strong and weak fiscal consolidation (for explanations, see the text above)

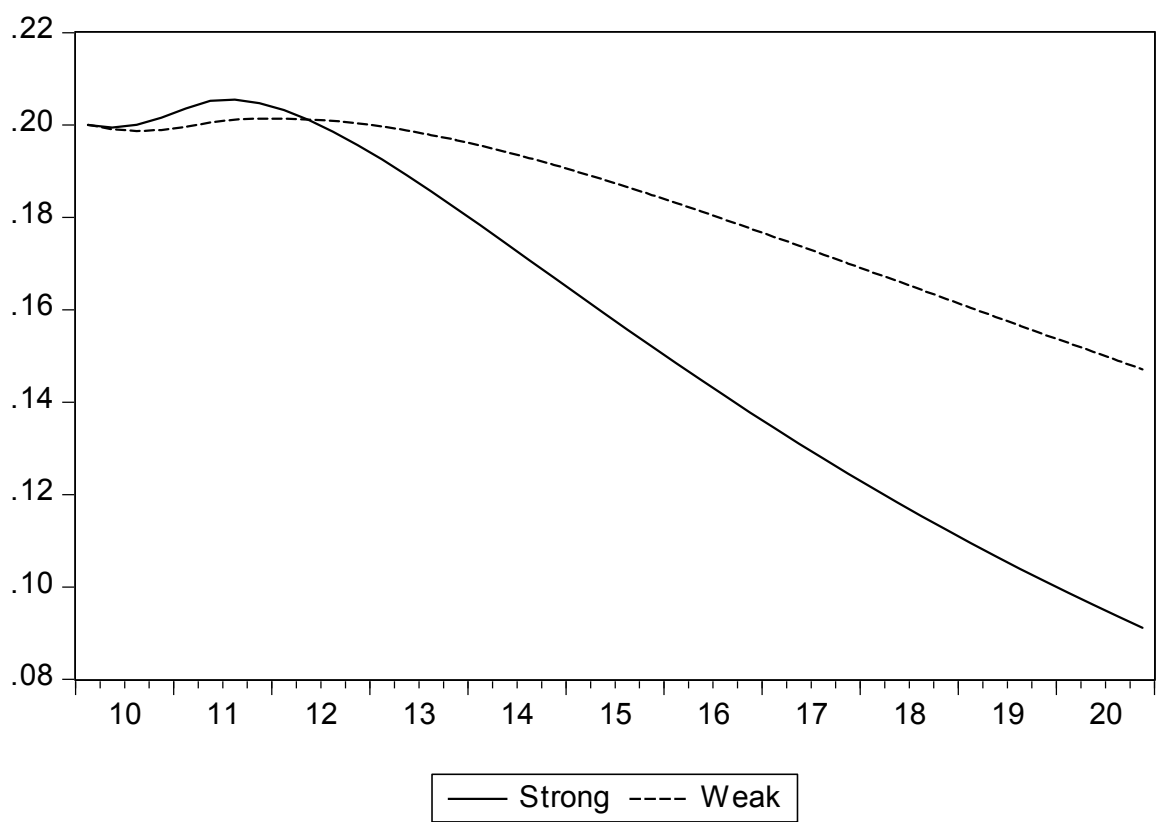

\subsection{Sustainability through structural reforms?}

The above results are quite gloomy in the sense that the high debt country runs into ever mounting debts in this decade even though the evolution of the debt may not be as such inconsistent with a no-Ponzi-game criteria. Let us therefore still find out under which kind of structural reforms to be adopted by the high-debt country it can turn its debt ratio into decline.

Define from the CES production function the dependence of the potential output on the capital stock $\mathrm{K}, \rho=\rho\left(Q^{P O T}, K\right)$ where $\rho$ is elasticity, and from the optimal investment equation,

$$
d \log K^{P O T}=d \log Q^{P O T}-\frac{1}{1-\sigma}[d \log (1+m u)+d \log (r-\pi+d)]
$$

where mu is the mark up factor in the goods market and $(1-\sigma)^{-1}$ is the elasticity of substitution and $\mathrm{d}$ is the rate of depreciation. We now have the expression for a change in the potential output

$$
d \log \left(Q_{i}^{P O T}\right)=-\frac{\rho}{(1-\sigma)(1-\rho)}\left[d \log \left(1+m u_{i}\right)+d \log \left(r_{i}-\pi_{i}+d_{i}\right)\right]
$$

The mark up factor has two kinds of effects. First, as in (22), it has an effect on the potential output. Secondly, it has an opposite effect on the inflation rate in (2). We now see that the problem country $(\mathrm{i}=1)$ needs to carry out reforms to such a magnitude that their impact outweighs their contractionary impact of the rise in the real financing costs.

Assume in a schematic way that the potential output of the problem country concerned grows permanently by 2 percentage points p.a. more than earlier, which is a huge amount, and as- 
Figure 11 The debt ratio in country 1 under strong structural reforms, in combination with a very strong fiscal consolidation*

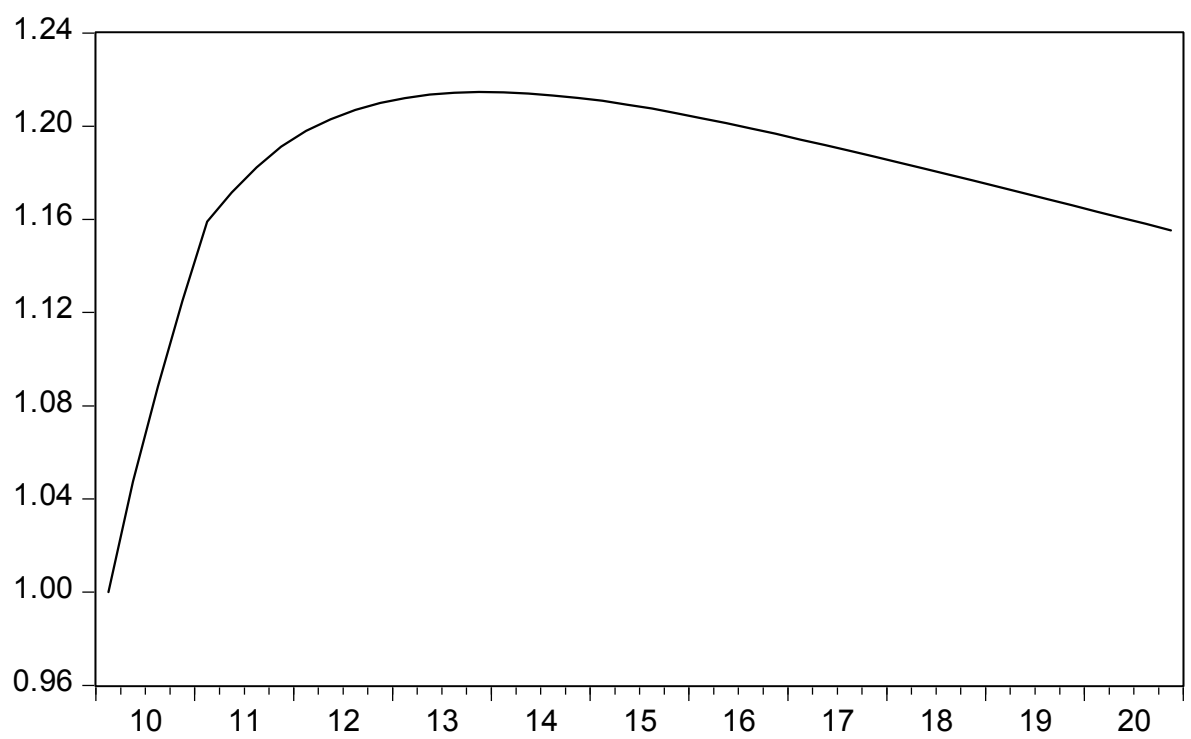

* For explanations, see the text above.

sume further that it cuts the annual inflation rate by 0.25 percentage points. Let us further assume that in the fiscal policy rule in Eq. (15) the parameter $h_{3}$ is fixed to a very strong value, to -0.03 (see Table 1 above). The outcome is the following, see Fig. 11. If there were no initial loss of competitiveness in country 1 , an acceleration of the potential growth rate by 0.5 percentage points p.a. would be enough to reach a similar levelling off and slight reduction in the debt ratio. This shows the large impact of the inherited loss of competitiveness as to restoring the sustainability of the euro.

\section{$6 \quad$ Concluding remarks}

We have analysed the case of EMU adjustment to an imbalance in terms of inflationary shocks and competitiveness and argued that the ECB is able to restore, although over time, the sustainability of the EMU also with respect to idiosyncratic shocks. We were able to reject the unsustainability result by Wickens $(2007,2010)$ and show that it does not hold within EMU in general. True, we did not address the issue, whether EMU as such is conducive to such imbalances to emerge. We also find that, even though the EMU would stay sustainable, the adjustment patterns with respect to the emerged imbalances entail a major polarisation within the Monetary Union likely leading to political tensions in it.

Above, we have basically taken two approaches to the issue of sustainability: a technical one concerning the existence of a determinate solution and a policy point of view playing its role in reality. Especially, as to the fiscal consolidation, we inferred that it takes a lot of time and the debt ratio in the problem country may mount to a very high level. ${ }^{5}$ This may make it implau- 
sible that the debtor country could reassure the financial markets of its solvency under such a scenario. This would call for a more stringent fiscal rule as to the adjustment in the country concerned. The problem with the adjustment is that strict fiscal policy leads to a cut in output, which leads to a higher debt ratio. This would call for an enlargement of the NKM model to describe the behaviour of the private sector under fiscal consolidation in the sense that a lower scenario of the public debt developments can have a boosting effect on private consumer behaviour through an expected reduction in taxation. On the other hand, we could expect that the public debt ratios rise also permanently because in private sector portfolios private assets are substituted by those of the public sector in the conditions of a financial crisis. We leave these issues for a future consideration. It should also be noted that we did not derive the global economy from an optimisation, as is normally done in NKM models.

Anyway, the mounting debt ratios in the problem countries cast a doubt on whether the EMU can successfully manage its current crisis. In the Spring of 2011 fears and speculation emerged that Greece would have to face a debt default. This would let the country $j=2$ to skip from interest rate subsidy extended to country $i=1$, but, on the other hand, it would have to bear the deflationary impact of the capital loss related to its debt extended to country $i=1$. The consequences for the debtor country would be a mirror image of this outcome. What it would imply for the monetary policy and stability of the banking sector falls outside the realm of the present paper, and we leave these aspects aside at this stage.

We inferred that far-reaching and successful structural reforms are sufficient to restore the sustainability of the euro in terms containing the public sector indebtedness, as it seems that in the case of rising future interest rates by the ECB austerity in the public finances may not be sufficient to achieve this alone. 


\section{References}

Alho, K.E.O., Kotilainen, M. and Nikula, N. (2010): Prospects of the Northern EU Integration (in Finnish), Central Chamber of Commerce, Finland, 2010.

Bergman, M. (2001): "Testing Government Solvency and the No Ponzi Game Condition”, Applied Economics Letters, Vol. 8, 27-29.

Commission (2008): EMU@10, Assessing the first 10 years and challenges ahead, Quarterly Report on the Euro Area, Vol. 7, No. 2, European Commission.

Galí, J. (2010): “Are Central Banks' Projections Meaningful?", CEPR, Discussion Paper, No. 8027.

Galí, J. and Monacelli, T. (2008): "Optimal Monetary and Fiscal Policy in a Currency Union", Journal of International Economics, Vol. 76, 116-132.

Ferrero, A. (2008): "Fiscal and Monetary Rules for a Currency Union", Journal of International Economics, Vol. 77, 1-10.

King, R.G. and Watson, M.R. (1998): "The Solution of Singular Linear Difference Systems under Rational Expectations", International Economic Review, Vol. 39, No. 4, 1015-1026.

Kirsanova, T., Leith, C. and Wren-Lewis, S. (2009): "Monetary and Fiscal Policy Interaction: The Current Consensus Assignment in the Light of Recent Developments", The Economic Journal, Vol. 199, No. 541, F482-F496.

Laubach, T. (2009): "New Evidence on the Interest Rate Effects of Budget Deficits and Debt", Journal of the European Economic Association, Vol. 7, Iss. 4, 858-885.

Leith, C. and Wren-Lewis, S. (2007): "Fiscal Sustainability in a New Keynesian Model”, Oxford University, Department of Economics, Discussion Paper Series, No. 310.

Lubik, T.A. and Schorfheide, F. (2004): "Testing for Indeterminacy: An Application to U.S. Monetary Policy", American Economic Review, Vol. 94, No. 1, 190-217.

Mavroeidis, S. (2010): "Monetary Policy Rules and Macroeconomic Stability: Some New Evidence", American Economic Review, Vol. 100, No. 1, 491-503.

Minford, P. and Srinivasan, N. (2010): “Determinacy in New Keynesian Models: A Role for Money after All?", CEPR, Discussion Paper, No. 7960.

OECD (2011): Economic Survey of Greece 2011.

Orjasniemi, S. (2010): The Effect of Openness in a Small Open Monetary Union", Bank of Finland, Discussion Papers, No. 18, 2010.

Sargent, T.J. (1989): Macroeconomic Theory, John Wiley.

Schabert, A. and van Wijnbergen, S.J.G. (2011): "Sovereign Default and the Stability of Inflation Targeting", Duisenherg School of Finance - Tinbergen Institute Discussion Paper, TI 11-064/2/ DSF 20.

Wickens, M.R. (2007): "Is the Euro Sustainable?", CEPR Discussion Paper, No. 6337.

Wickens, M.R. (2010): "Is the Euro the Success that Everyone Seems to Think?", Open Economics Review, Vol. 21, 183-185.

Woodford, M. (2003): Interest \& Prices - Foundations of a Theory of Monetary Policy, Princeton University Press. 


\section{Appendix 1 \\ Derivation of the IS curve in Eq. (1)}

We start from the goods market equilibrium, written in terms of log deviations from the steady state

$$
q_{i t}=w_{C} c_{t}+w_{I} i_{t}+w_{X} x_{t}-w_{M} m+z_{i t}+\varepsilon_{i t},
$$

where $\mathrm{q}$ is the output gap, $\mathrm{c}$ is consumption expenditure, i investment, $\mathrm{x}$ exports and $\mathrm{m}$ imports (measured in terms of the domestic price level) and the $w_{i}$ 's are the equilibrium shares of respective variables in relation to output. From an intertemporal optimisation we derive the consumption expenditure

$$
c_{i, t}^{-v}=E\left[c_{i, t+1}^{-v}\left(1+r_{t}-\pi_{i, t+1}\right)\right] .
$$

Based on the cost minimisation by firms we can write the following investment equation

$$
i_{i, t}=E q_{i, t+1}-\tau\left(r_{t}-E \pi_{i, t+1}\right) .
$$

The export equation is based on the import demand function, which are typically, for the country k

$$
m_{k, t}=q_{k, t}-\delta \operatorname{comp}_{k, t},
$$

where comp is the competitiveness term, i.e. real exchange rate and $\delta$ is the relevant elasticity of substitution. We divide exports and imports to those of the EMU country with the EMU partner and rest of the world, with shares of $\mathrm{w}_{\mathrm{k}, \mathrm{EMU}}$ and $\mathrm{w}_{\mathrm{k}, \mathrm{RESST}}, \mathrm{k}=\mathrm{X}, \mathrm{M}$, summing to unity. Let us approximate the future consumption deviation from equilibrium as being identical to the expected output deviation which holds approximately in the equilibrium where consumption is a fixed share of output. Then, altogether, we can derive the following IS-curve,

$$
\begin{aligned}
& \left(1+w_{M}\right) q_{i, t}=\left(w_{C}+w_{I}\right) E q_{i, t+1}-\left(v^{-1}+\tau\right)\left(r_{t}-E \pi_{i, t+1}\right)+w_{X} w_{X, \operatorname{Res} t} q_{t}^{*}+w_{X} w_{X, E M U} q_{j, t}+ \\
& \left(w_{X} w_{X, \operatorname{Re} s t}+w_{M} w_{M, \operatorname{Re} s t}\right) \delta c o m p_{i t}+\left(w_{X} w_{X, E M U}+w_{M} w_{M, E M U}\right) \delta\left(p_{j t}-p_{i t}\right)+z_{i, t} .
\end{aligned}
$$

This is the basis of our specification of the IS curve in (1) above. We see that open economy specification crucially lowers the coefficient of the expected output gap to be lower than unity, which has a major impact on the stability of the model.

We assume that the EMU is a small open region in the sense that it does not have an impact on the global economy, so that the global output gap $\mathrm{q}^{\star}$ obeys the developments influenced by a demand shock mentioned above in Section 5.2. 


\section{Appendix 2}

Latent roots of the $\mathrm{H}$ matrix on page 7

From the model for the aggregate euro area (Eqs. (7) and (8)) as a function of the parameter $\omega_{2}$ in Eq. (17) we get the following latent roots for the $\mathrm{H}$ matrix on page 7.

Figure A1 The latent roots of the aggregate euro area model as a function the parameter $\omega_{2}$ (omega2) in Eq. (12)

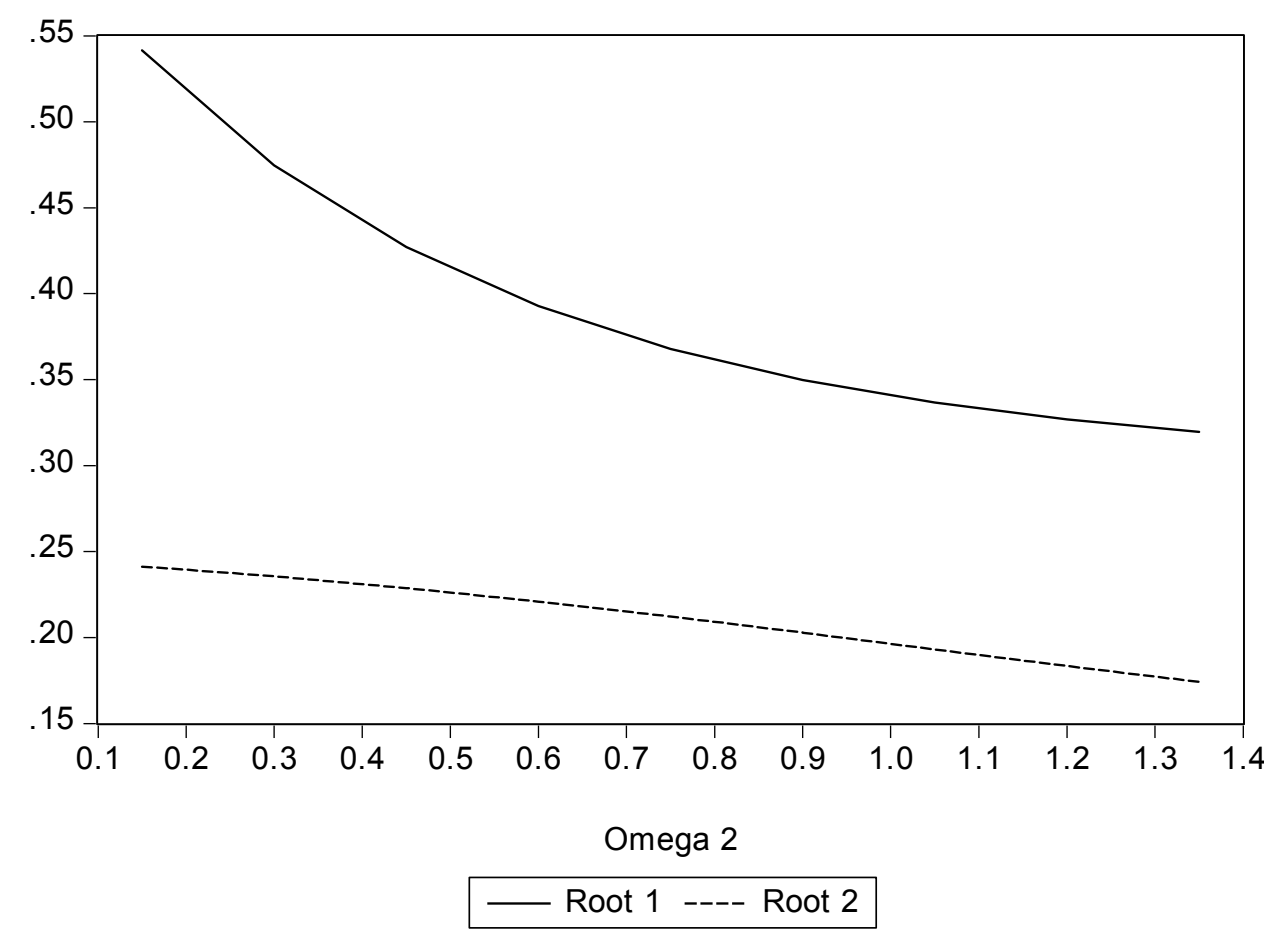

For the difference model in Eq. (11) we get the following outcomes. 
Figure A2 The latent roots of the $\mathrm{H}$ matrix on p. 7 of the difference model (11) as a function of the coefficient (fii), impact of competitiveness on output

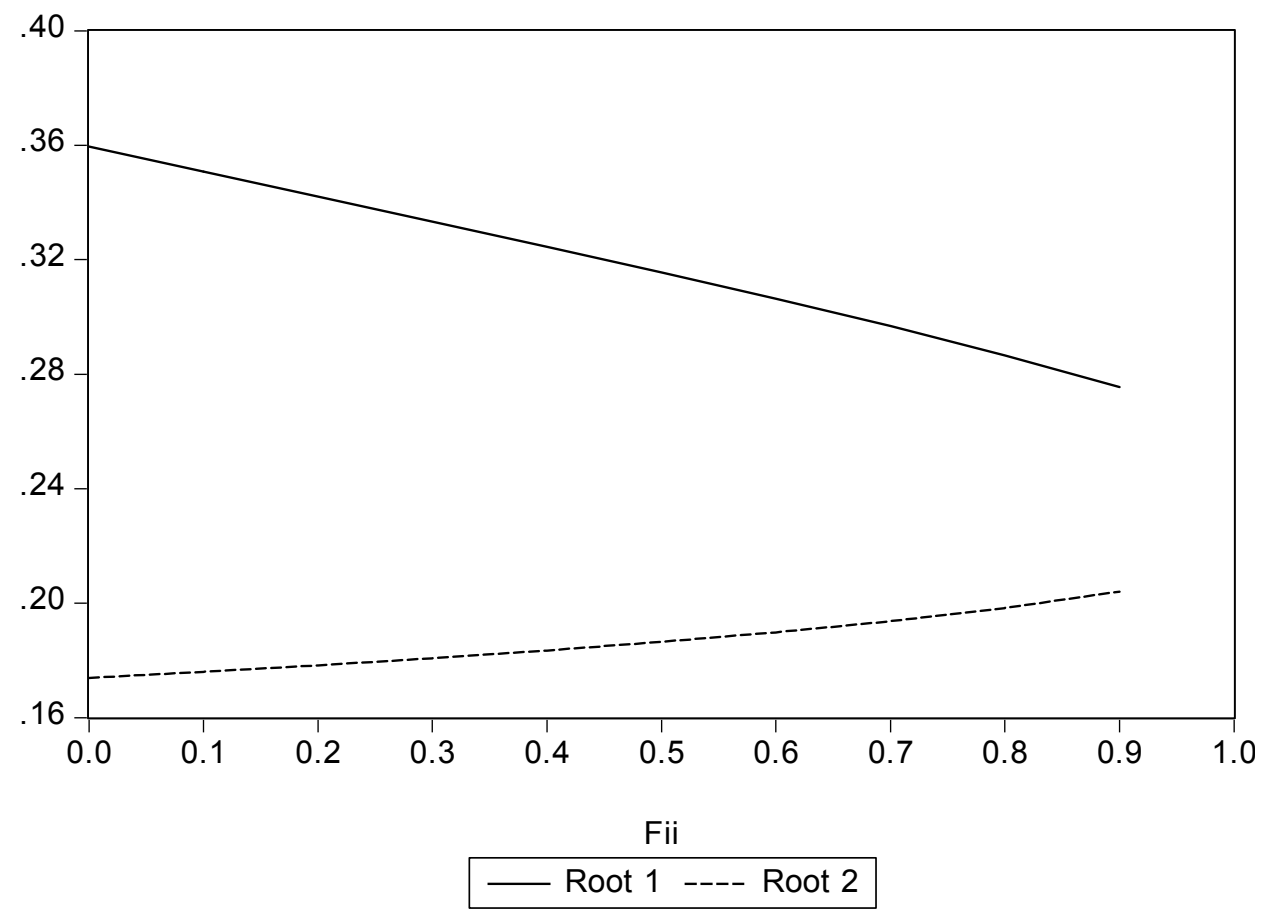

Figure A3 Latent roots of the $\mathrm{H}$ matrix on $\mathrm{p} .7$ of the difference model (11) as a function of the coefficient $\gamma$ (gamma), impact of expected output on current output

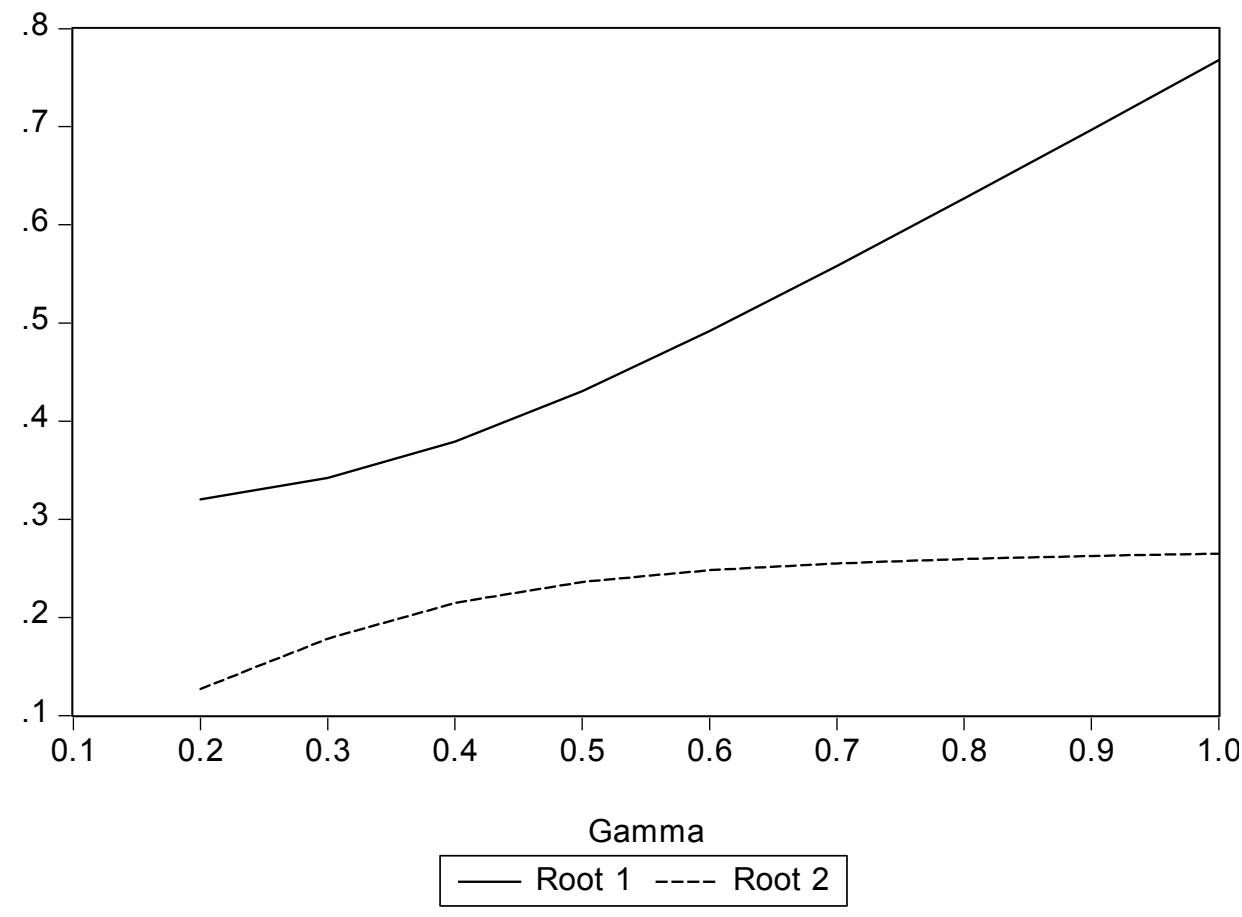




\section{Appendix 3 \\ The characteristic roots of the extended system for fiscal policy analysis in Section 5.2.}

The model comprising of the fiscal policy block has ten endogenous variables $\left(\mathrm{q}_{1 \mathrm{t}}, \pi_{1 \mathrm{t}}, \mathrm{r}_{1 \mathrm{t}}, \mathrm{d}_{1 \mathrm{t}} ; \mathrm{q}_{2 \mathrm{t}}\right.$ $\left., \pi_{2 t} r_{2 t}, d_{2 t} ; r_{t}, s_{t}\right)$, with four forward-looking variables $\left(\mathrm{Eq}_{1, t+1}, \mathrm{E}_{1, t+1}, \mathrm{Eq}_{2, t+1}, \mathrm{E}_{2, t+1}\right)$.

Of the characteristic roots of the corresponding matrix $H=A_{o}^{-1} A_{1}$ (see page 7) are four nonzero and six zero. We have varied the in the monetary policy rule the coefficient of the inflation target in Eq. (12). The largest characteristic root behaves as follows.

Table A1 The characteristic root of the model enlarged with a block of fiscal policy

Weight of inflation ( $\omega 2)$ in the

monetary policy rule in Eq. (12)

0.25

0.5

0.75

1

1.25

1.5
The largest characteristic root

in absolute value

0.676

0.644

0.616

0.59

0.566

0.544

This confirms that the model is stable for a wide range of parameter values. 




\section{Aikaisemmin ilmestynyt ETLAn Keskusteluaiheita-sarjassa Previously published in the ETLA Discussion Papers Series}

No 1244 Antti Kauhanen - Sami Napari, Career and Wage Dynamics. Evidence from Linked Employer-Employee Data. 25.03.2011. 28 p.

No 1245 Kari E.O. Alho, Should Sweden Join the EMU? An Analysis of General Equilibrium Effects through Trade. 06.04.2011. $16 \mathrm{p}$.

No 1246 Heli Koski - Mika Pajarinen, The Role of Business Subsidies in Job Creation of Start-ups, Gazelles and Incumbents. 07.04.2011.21 p.

No 1247 Antti Kauhanen, The Perils of Altering Incentive Plans. A Case Study. 08.04.2011. 22 p.

No 1248 Rita Asplund - Sami Napari, Intangible Capital and Wages. An Analysis of Wage Gaps Across Occupations and Genders in Czech Republic, Finland and Norway. 11.04.2011. 18 p.

No 1249 Mari Kangasniemi - Antti Kauhanen, Performance-related Pay and Gender Wage Differences. 21.04.2011. $19 \mathrm{p}$.

No 1250 Ye Zhang, Wireless Acquisition of Process Data. 24.05.2011. 52 p.

No 1251 Rita Asplund - Erling Barth - Per Lundborg - Kjersti Misje Nilsen, Challenges of Nordic Labour Markets: A Polarization of Working Life? 08.06.2011.21 p.

No 1252 Jari Hyvärinen, Innovaatiotoiminta: Näkemyksiä ympäristö- ja energia-alaan. 1.6.2011. 39 s.

No 1253 Ari Hyytinen - Mika Maliranta, Firm Lifecycles and External Restructuring. 17.06.2011.34 p.

No 1254 Timo Seppälä-Olli Martikainen, Europe Lagging Behind in ICT Evolution: Patenting Trends of Leading ICT Companies. 22.06.2011. 18 p.

No 1255 Paavo Suni-Pekka Ylä-Anttila, Kilpailukyky ja globaalin toimintaympäristön muutos. Suomen koneteollisuus maailmantaloudessa. 19.08.2011. $39 \mathrm{~s}$.

No 1256 Jari Hyvärinen, Innovaatiotoiminta: Näkemyksiä hyvinvointialaan ja työelämän kehittämiseen. 31.8.2011. $28 \mathrm{~s}$.

No 1257 Terttu Luukkonen - Matthias Deschryvere - Fabio Bertoni - Tuomo Nikulainen, Importance of the Non-financial Value Added of Government and Independent Venture Capitalists. 2.9.2011. 28 p.

No 1258 Ari Hyytinen - Mika Pajarinen - Pekka Ylä-Anttila, Finpron vaikuttavuus - Finpron palveluiden käytön vaikutukset yritysten kansainvälistymiseen ja menestymiseen. 15.9.2011. 32 p.

Elinkeinoelämän Tutkimuslaitoksen julkaisemat "Keskusteluaiheita" ovat raportteja alustavista tutkimustuloksista ja väliraportteja tekeillä olevista tutkimuksista. Tässä sarjassa julkaistuja monisteita on mahdollista ostaa Taloustieto Oy:stä kopiointi- ja toimituskuluja vastaavaan hintaan.

Papers in this series are reports on preliminary research results and on studies in progress. They are sold by Taloustieto Oy for a nominal fee covering copying and postage costs.

Julkaisut ovat ladattavissa pdf-muodossa osoitteessa: www.etla.fi/julkaisuhaku.php

Publications in pdf can be downloaded at www.etla.fi/eng/julkaisuhaku.php

ETLA

Elinkeinoelämän Tutkimuslaitos

The Research Institute of the Finnish Economy

Lönnrotinkatu 4 B

00120 Helsinki

ISSN 0781-6847
Puh. 09-609 900

Fax 09-601753

www.etla.fi

etunimi.sukunimi@etla.fi 